\title{
Increase and Patterns of Spread of Citrus Tristeza Virus Infections in Costa Rica and the Dominican Republic in the Presence of the Brown Citrus Aphid, Toxoptera citricida
}

\author{
T. R. Gottwald, S. M. Garnsey, and J. Borbón
}

First and second authors: USDA-ARS, Orlando, FL 32803; and third author: Junta Agroempresarial Dominicana, Inc., Santo Domingo, Republica Dominicana.

Accepted for publication 24 March 1998.

\begin{abstract}
Gottwald, T. R., Garnsey, S. M., and Borbón, J. 1998. Increase and patterns of spread of citrus tristeza virus infections in Costa Rica and the Dominican Republic in the presence of the brown citrus aphid, Toxoptera citricida. Phytopathology 88:621-636.

Citrus tristeza virus (CTV) was monitored for 4 years by monoclonal antibody probes via enzyme-linked immunosorbent assay in four citrus orchards in northern Costa Rica and four orchards in the Dominican Republic following the introduction of the brown citrus aphid, Toxoptera citricida. The Gompertz nonlinear model was selected as the most appropriate in most cases to describe temporal increase of CTV. Ordinary runs analysis for association of CTV-positive trees failed to show a spatial relationship of virus status among immediately adjacent trees within or across rows. The beta-binomial index of dispersion for various quadrat sizes suggested aggregations of CTV-positive trees for all plots within

sizes up to four lag distances; however, significant lag positions discontinuous from the main proximity pattern were rare. Some asymmetry was also detected for some spatial autocorrelation proximity patterns. These results were interpreted to mean that, although CTV-positive trees did not often influence immediately adjacent trees, virus transmission was common within a local area of influence that extended two to eight trees in all directions. Where asymmetry was indicated, this area of influence was somewhat elliptical. The spatial and temporal analyses gave some insight into possible underlying processes of CTV spread in the presence of T. citricida and suggested CTV spread was predominantly to trees within a local area. Patterns of longer-distance spread were not detected within the confines of the plot sizes tested. Longer-distance spread probably exists, but may well be of a complexity beyond the detection ability of the spatial analysis methods employed, or perhaps is on a scale larger than the dimensions of the plots studied.
\end{abstract} the quadrat sizes tested. Spatial autocorrelation analysis of proximity patterns suggested that aggregation often existed among quadrats of various
Additional keywords: Aphis gossypii.
The citrus tristeza virus (CTV) pathosystem is complex. Isolates of CTV vary greatly in symptom expression, and a multitude of interactions can occur due to various combinations of the virus, host tree, aphid vector species, and environment. One of the most destructive diseases of citrus, CTV quick decline, is caused by certain CTV isolates that elicit a graft union incompatibility when infected sweet orange scions are grafted onto sour orange rootstocks. By 1987, over 50 million citrus trees grafted on sour orange were killed following infection by decline-inducing isolates of CTV worldwide. In Spain alone, more than 17 million trees of sweet orange and mandarins grown on sour orange rootstock have died $(1,8,9,36)$.

Four aphid species (Aphis gossypii, the cotton or melon aphid; A. spiraecola, the spirea aphid; Toxoptera aurantii, the black citrus aphid; and Toxoptera citricida, the brown citrus aphid) have been associated with the natural movement of CTV $(2,14,15,25$, 26,39,40,44-46). The most efficient vector of CTV worldwide is T. citricida $(20,23,39,46)$. T. citricida is up to 25 times more efficient at transmitting CTV isolates than the next most efficient

Corresponding author: T. R. Gottwald; E-mail address: gott@magicnet.net

Mention of a trademark, warranty, proprietary product, or vendor does not constitute a guarantee by the USDA and does not imply its approval to the exclusion of other products or vendors that may also be suitable.

Publication no. P-1998-0504-01R

This article is in the public domain and not copyrightable. It may be freely reprinted with customary crediting of the source. The American Phytopathological Society, 1998. vector species, A. gossypii (45). A. gossypii is apparently the primary vector of CTV in locations such as California, Spain, and Israel, where T. citricida is absent, although the role of A. spiraecola in field spread of CTV has never been fully resolved. Vector efficiency and transmission studies combined with aphid-trapping studies in citrus have demonstrated that $A$. gossypii populations in citrus coincided with and were sufficient to account for increases in CTV infections observed $(14,15,20,25,36,40,46)$. Citrus is not a primary host for A. gossypii, which does not heavily colonize citrus, and vectoring of CTV may be due to migrants through the orchards from surrounding areas or crops. In contrast, citrus is the primary host for $T$. citricida, and large colonies of this aphid are found under favorable conditions $(3,40,46)$.

T. citricida has recently spread northward from South America into most islands in the Caribbean and into Central America (39). It was discovered in southeast Florida in 1995 and is spreading into all major citrus areas (45). The spatial and temporal dynamics of CTV appear to change as T. citricida becomes part of the pathosystem, but most of this information is anecdotal $(39,45)$. The United States citrus industry and citrus industries of other nations of the Caribbean and Central America are concerned that the presence of T. citricida will result in elevated CTV increase, spread, and CTV-related tree and crop losses $(39,45)$.

Spatial and temporal analyses of CTV epidemics have been conducted previously, but mostly from limited data and almost exclusively for CTV decline, for which A. gossypii was believed to be the major vector $(2,12,13,16,21,34)$. Recently, using data from intensely mapped multi-year studies of CTV incidence in eastern Spain and Florida, Gottwald and others (21,22; T. R. Gottwald, S. M. Garnsey, and M. Irey, unpublished data) found that, for CTV 
epidemics in areas where A. gossypii was the predominant CTV vector, CTV incidence progressed from low levels $(\sim 0.05)$ to high levels $(\sim 0.95)$ in 8 to 15 years. For the Spanish data, there was little evidence for aggregation of CTV-infected trees, and the spatial patterns of CTV-infected trees could not be distinguished from a random pattern. Virus spread did not occur preferentially to trees adjacent to those already infected. Rather, new infections probably arose from both inter- and intraplot transmissions (21). Hughes et al. (28) and Gibson (19) recently reevaluated the same data from eastern Spain. Using all of the Spanish CTV data collectively, Hughes et al. (28) found that the data could be fitted by binomial distributions with a separate mean incidence for each assessment, but with a common aggregation parameter, equal to 0.03 . The low value of the aggregation parameter and the proximity of the data points to the theoretical binomial line in a plot of observed variance against binomial variance are indicative of a random pattern at the quadrat scale (28). Gibson (19) examined the data using a spatio-temporal stochastic model based on Markov chain, Monte Carlo integration methods. Gibson's analyses reinforced the interand intraplot transmission theory and provided some evidence that one component of spread was likely due to short-distance transmissions from nearby trees, which was not apparent from the analytical methods used by Gottwald et al. $(19,21)$.

The study of CTV increase and spread requires determination of the virus status of individual trees repeatedly over time. A number of polyclonal and monoclonal antibodies have been prepared to CTV and a variety of enzyme-linked immunosorbent assay (ELISA) protocols have been established that can be adapted for large-scale testing $(5-7,17,38,42,43)$. Individual trees are assayed by ELISA and the presence or absence of CTV virus determined.

Methods for the quantitative analysis of spatial patterns at a single point in time exist that take advantage of the binary (i.e., presence or absence) data generated by ELISA methods. Ordinary runs is a unidirectional analysis that can be used to assess aggregation within columns or rows in a population matrix of diseased plants (33). The beta-binomial discrete distribution is the most appropriate distribution to examine spatial patterns of disease incidence of binary data for the presence of aggregation within quadrats of different sizes $(27,31)$. Spatial autocorrelation analysis (SAA) can be used with binary, as well as quantitative, data to analyze the spatial pattern of disease incidence between quadrats $(10,11$, 24,35,37). Madden and Hughes (32) suggested that, for analysis of disease incidence data, the simultaneous study of correlations both within (such as that provided by beta-binomial distribution analysis) and between quadrats (such as provided by SAA) presents interesting new possibilities for epidemic quantification.

Studies on the spatial and temporal dynamics of CTV isolates in the presence of $T$. citricida have not been attempted. The expansion of the distribution range of $T$. citricida into Central America, the Caribbean, and most recently Florida created the need for more detailed estimates of the rate of temporal increase and patterns of spread of CTV in these tropical and subtropical climates to better evaluate the expected productive life of citrus orchards affected by tristeza and the potential efficacy of various control strategies. CTV suppression and eradication programs currently exist in central California, Florida, and Texas to detect new and exotic CTV isolates that threaten the industries in these states. Removal of CTV-infected trees is the mainstay of suppression and eradication efforts, and tree removal efforts must be sufficient to offset the estimated CTV increase and thereby suppress the virus epidemic. The introduction of a more efficient vector to these areas (i.e., $T$. citricida) is cause to reevaluate the current rates of tree removal.

Survey methods for detection of CTV-infected trees are based on the spatial pattern of CTV in a planting $(27,28)$. Spatial patterns of CTV-infected trees were shown to be indistinguishable from random when the predominant vector was A. gossypii; however, this does not appear to be the case when $T$. citricida is the predominant aphid vector species $(21,22,29 ;$ T. R. Gottwald and
G. Hughes, unpublished data). Therefore, a greater understanding of spatial and spatiotemporal dependency of CTV is needed to address survey and eradication/suppression issues.

The purpose of this study was to examine the spatial, temporal, and spatio-temporal dynamics of CTV in Costa Rica and the Dominican Republic, where T. citricida is firmly established and citrus cultivars, citriculture practices, and CTV isolates are similar to those in the United States. Our overall goal was to determine likely rates of CTV increase and spatial patterns of spread, and by detailed analysis, to better understand dissemination of CTV in the presence of $T$. citricida. A preliminary analysis of a portion of the data presented in this report, but with less rigorous analytical techniques and for fewer years, has been published previously (22).

\section{MATERIALS AND METHODS}

Experimental design. Data were collected over a 4-year period from plots established in commercial citrus plantations including four plots in the Guanacaste province of northern Costa Rica and four plots in southeastern Dominican Republic. All plots consisted of approximately 20 rows of trees, each with 20 trees per row, in a rectangular planting pattern within larger commercial plantings, and plantings ranged from 1 to 5 years old at the beginning of the study. The Costa Rica plots were designated as follows: CR1 = a pineapple sweet orange planting on Cleopatra mandarin rootstock, located near Los Inocentes; CR2 = a Valencia sweet orange planting on Cleopatra mandarin rootstock, located near Birmania; CR3 = a Valencia sweet orange planting on local grapefruit rootstock, located near Brazilia; and CR4 = a pineapple sweet orange planting on carrizo rootstock, located near Los Inocentes. The Dominican Republic plots were designated as follows: DR1 = a Valencia sweet orange planting on carrizo rootstock, located near La Lecheria; $\mathrm{DR} 2$ = a Valencia sweet orange planting on carrizo rootstock, located near Bayaguana; DR3 = a Marsh grapefruit planting on Swingle citrumelo rootstock, located near Hato Mayor; and DR4 = a Valencia sweet orange planting on sour orange rootstock, located near Hato Mayor. No aphid control procedures were applied in any of the plots. T. citricida was present in all locations when the experiments were started.

Sample collection. Plots were sampled in spring and fall each year, and every tree was tested independently. Samples consisted of four petioles from young, nearly fully expanded leaves taken from the periphery of each tree. The four petioles from each tree were placed in a number-coded paper envelope, and 20 individual envelopes corresponding to one row of trees were placed in sealable plastic bags, to which was added approximately $50 \mathrm{~g}$ of a moisture-indicating silica gel (Tel-Tale, grade 42; Grace Davison, Baltimore, MD). The silica gel was changed as needed to ensure that the specimens dried completely. The dry samples were then transported to the United States Department of Agriculture-Agriculture Research Station (USDA-ARS) laboratory in Orlando, FL, for processing.

ELISA processing. The four leaf petioles of each sample were placed in $5 \mathrm{ml}$ of phosphate-buffered saline (PBS)-Tween buffer and pulverized for $30 \mathrm{~s}$ in a Kleco tissue pulverizer (Garcia Manufacturing, Visalia, CA). Extracts were assayed for presence of CTV via double-sandwich indirect (DAS-I)-ELISA (18). Isolates of CTV were differentiated into two groups designated here as mild (nondecline-inducing) and severe (potentially decline- or stem-pittinginducing) isolates. These designations were based on differential reaction to two monoclonal probes. The first probe consisted of a mixture of the monoclonal antibodies $11 \mathrm{~B} 1$ and 3E10, which in combination act as a universal probe for all known isolates of CTV (18; S. M. Garnsey, M. Cambra, and M. Tasi, unpublished data). The second probe consisted of the single monoclonal antibody MCA13, which reacts to the majority of decline-inducing and stem-pitting isolates of CTV, but does not react to mild isolates found in Florida (38). Thus, a sample reacting to the uni- 
versal probe, but not MCA13, was designated "mild," whereas a sample that reacted to both probes was designated "severe."

Temporal analysis. The disease incidence (number of CTV-infected trees divided by the total number of trees in the plot) of each plot was calculated for each year. Nonlinear regression analysis of nontransformed data from each plot was performed for the nonlinear forms of linear, exponential, monomolecular, logistic, and Gompertz models (SAS NLIN procedure using the DUD option, version 6.04; SAS Institute, Inc., Cary, NC). The appropriateness of each model was determined by examining the coefficient of regression, the correlation coefficient of observed versus detransformed predicted values, and the plots of standardized residual values versus predicted values. General model types were selected based initially on the shape of the disease progress curve. Models were further evaluated for the highest coefficient of correlation and were chosen as superior if no patterns were found in the residual plots $(4,10,30)$.

Spatial analysis. To interpret the relationships among CTVpositive trees, CTV data were examined at three discrete hierarchical levels: between adjacent individual trees, within quadrats of various sizes, and among quadrats of various sizes. Ordinary runs analyses were performed on each data set to determine if aggregation existed between adjacent CTV-positive trees within rows, across rows, or both with the use of a Visual Basic EXCEL macro (33; T. R. Gottwald, unpublished data). A nonrandom pattern (i.e., aggregation) of CTV-positive trees was assumed for a particular row if the observed was less than the expected number of runs at $P=0.05$.

To examine the data for the presence of aggregation at different spatial scales, the CTV incidence data from each block were partitioned into quadrats of 2 by 2, 2 by 3,3 by 2,3 by 3 , and 4 by 4 trees with the use of a Visual Basic EXCEL macro (T. R. Gottwald, unpublished data). The 2 by 3 and 3 by 2 quadrat sizes were used to test for a directional orientation to aggregation. Aggregation within quadrat was assessed via beta-binomial analysis, whereas aggregation between quadrats was assessed by spatial autocorrelation analysis. The index of dispersion $\left(I_{\beta}\right)$ associated with the beta-binomial distribution was used to test for the presence of aggregation of CTV-positive trees at each quadrat size $(27,31)$. For the beta-binomial index, a large $I_{\beta}(>1)$ combined with a small $P(<0.05)$ suggests aggregation of diseased trees $(27,31)$.

The strength and directionality or orientation of aggregation among quadrats of various sizes containing CTV-positive trees in each citrus plot were examined with spatial autocorrelation analysis using the LCOR2 software program because of its ability to handle quantitative values for each tree (24). For the spatial autocorrelation analysis, the $x, y$ spatial location and disease incidence of trees for each quadrat size on each assessment date in the individual citrus plots were used as input data. The program calculated proximity patterns of positively correlated lag positions (SL+) from which measurements of spatial patterns were calculated. The size and shape of core and reflected clusters of SL+ were calculated, in which a core cluster $=$ a group of significant, positively correlated $(P=0.05)$, spatial lag distance classes that form a discreet and contiguous group with the origin (i.e., lag [0.0]) of the autocorrelation proximity pattern; and a reflected cluster $=\mathrm{a}$ discrete group of two or more significant positive lag distance positions discontiguous with the origin, core cluster, or both. The strength of aggregation $=$ a measure of the saturation of the core clusters with significantly positive lags (i.e., the proportion of lag positions within the extents of the cluster that were significantly positive). Row effects $=$ the number of significant lag distance positions within the first row (within) or within the first column (across) of the autocorrelation proximity pattern that are contiguous with the origin $(10,11,35,37,41)$. Moran's $I$ autocorrelation index was also calculated as an overall measure of aggregation for each plot by assessment date using the SAAP software program (D. Wartenberg,
Department of Environmental and Community Medicine, Robert Wood Johnson Medical School, Piscataway, NJ).

\section{RESULTS}

CTV temporal progress. CTV was detected in each of the plots, with the exception of CR4 and DR3, during the first assessment. Recognizable patterns of CTV-infected trees did not exist in six of the eight plots studied (Figs. 1 and 2). However, plot CR3 had a block of the CTV-infected trees located in the first six rows of trees on the western border of the plot. Examination of plantation records revealed that the first six rows in CR3 were established from a different budwood source, which must have been infected with CTV. Thus, for CR3, the first six rows of CTV-infected trees served as a source of inoculum for the remaining 14 rows of trees to the east (Fig. 1). These six rows were removed from spatial analyses for total CTV for plot CR3, because they would have forced indications of aggregation in all cases. Plot DR2 also had a distinct line source of CTV-infected trees consisting of the majority of trees located in the middle five north-south rows of the plot (Fig. 2). However, in plot DR2, this distribution of CTV-positive trees appeared to be a product of natural spread and, thus, these rows were maintained in all spatial analyses. Epidemics of CTV within six of the eight plots progressed rapidly during the 4 years of the study (Fig. 3). The two plots for which CTV incidence progressed more slowly were CR4, a new planting geographically separated from, and in a much drier and more windy location than, the other northern Costa Rica plots; and DR3, a plot of grapefruit trees located in the same heavily infected area of the Dominican Republic as plot DR4 of Valencia orange trees, for which CTV incidence increased rapidly. Possible explanations for the lack of appreciable CTV increase in CR4 and DR3 are discussed below. For the remainder of the six plots, disease progressed to or near asymptotic levels during the approximately 4-year duration of the study (Fig. 3).

In three plots, CR2, CR3, and DR2, total CTV incidence was already 0.2 to 0.5 at the beginning of the study. Therefore, temporal modeling was only performed for data from DR1, DR4, and CR1 for all CTV isolates, and only for severe CTV in CR1 and CR3. In these cases, the shape of the disease progress curve was asymmetrically sigmoid, and the nonlinear Gompertz model was the most appropriate (data not shown). The most rapid increase occurred in DR4, in which CTV incidence increased from 0.01 to 0.998 in 3.75 years. Gompertz models indicated that mild and severe CTV isolates were capable of increasing from low to asymptotic incidence in orange plantings within 3.5 to 6.0 years.

Spatial arrangement of CTV-infected trees. The first level of spatial hierarchy examined was the association of virus status between adjacent trees. Although aggregation of CTV-positive trees within and across rows was detected by ordinary runs analysis in many of the CTV plots at various assessment dates, the percentage of within- and across-row tests indicating aggregation was low (Tables 1 and 2). These findings indicate that CTV-positive trees did not greatly influence the virus status of immediately adjacent trees within or across rows. Due to the high virus incidence in plots CR2, CR3, DR2, and DR4 during the final three to four assessment dates, ordinary runs analysis was not performed for those plots. For those few cases in which aggregation was detected via ordinary runs analysis, there was no consistent or significant association with direction of spread in any of the plots examined, indicating that CTV-positive trees were not necessarily associated with those immediately adjacent.

The next level of spatial hierarchy examined was the association of virus status within quadrats of various sizes. Interpretation of the $I_{\beta}$ index of dispersion values suggested significant nonrandom spatial structure (i.e., aggregation) of CTV-positive trees occurred for many plots and quadrat sizes over time when the CTV incidence was $>0.1$ and $<0.9$ (Tables 3 and 4). Within this incidence 
Sample

Date

Plot 1 (Upper Chon)

Oct '92

$0 \mathrm{yr}$
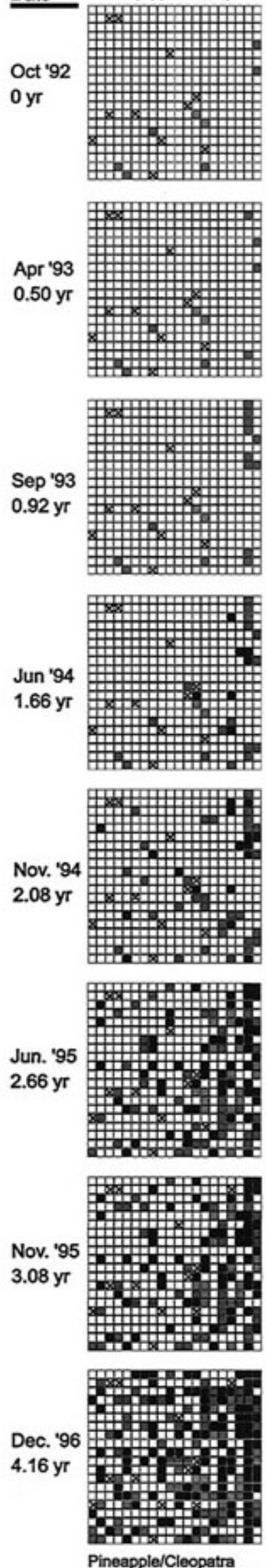
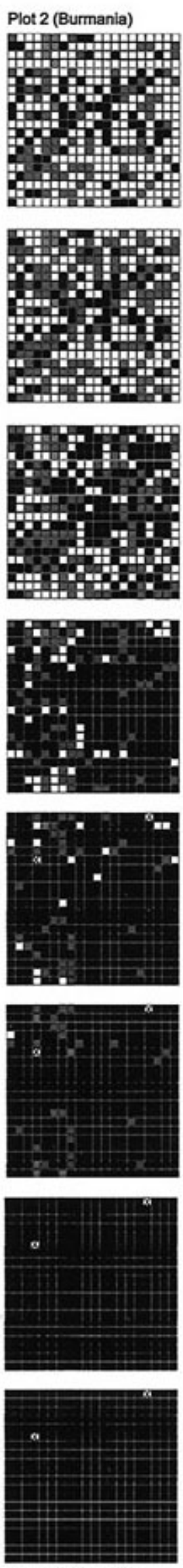

Valencia/Cleopatra
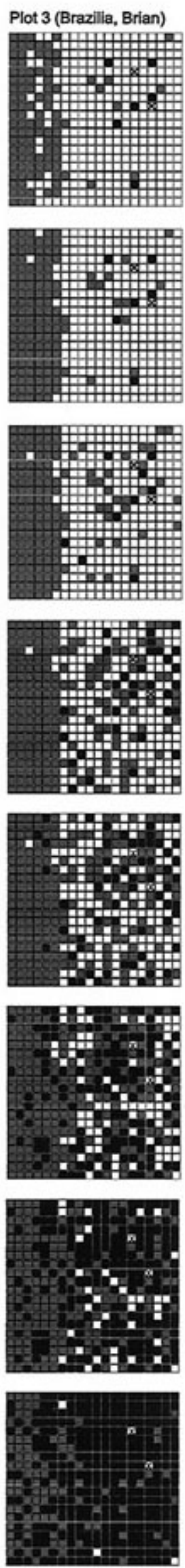

Valencia/grapefruit
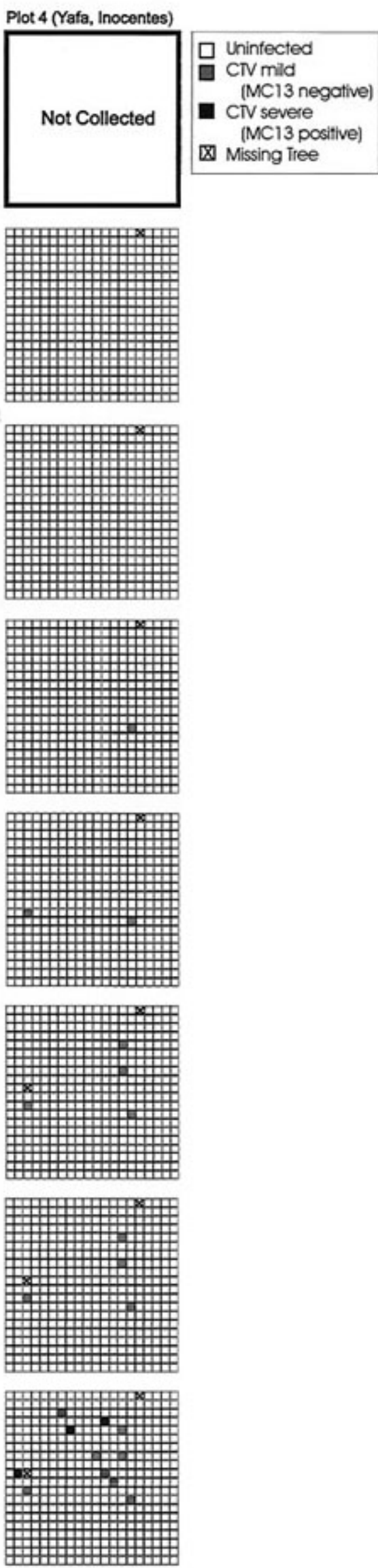

Pineapple/carrizo

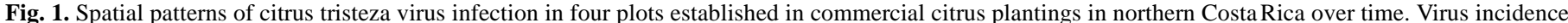
for all trees in each plot was determined by enzyme-linked immunosorbent assay. 


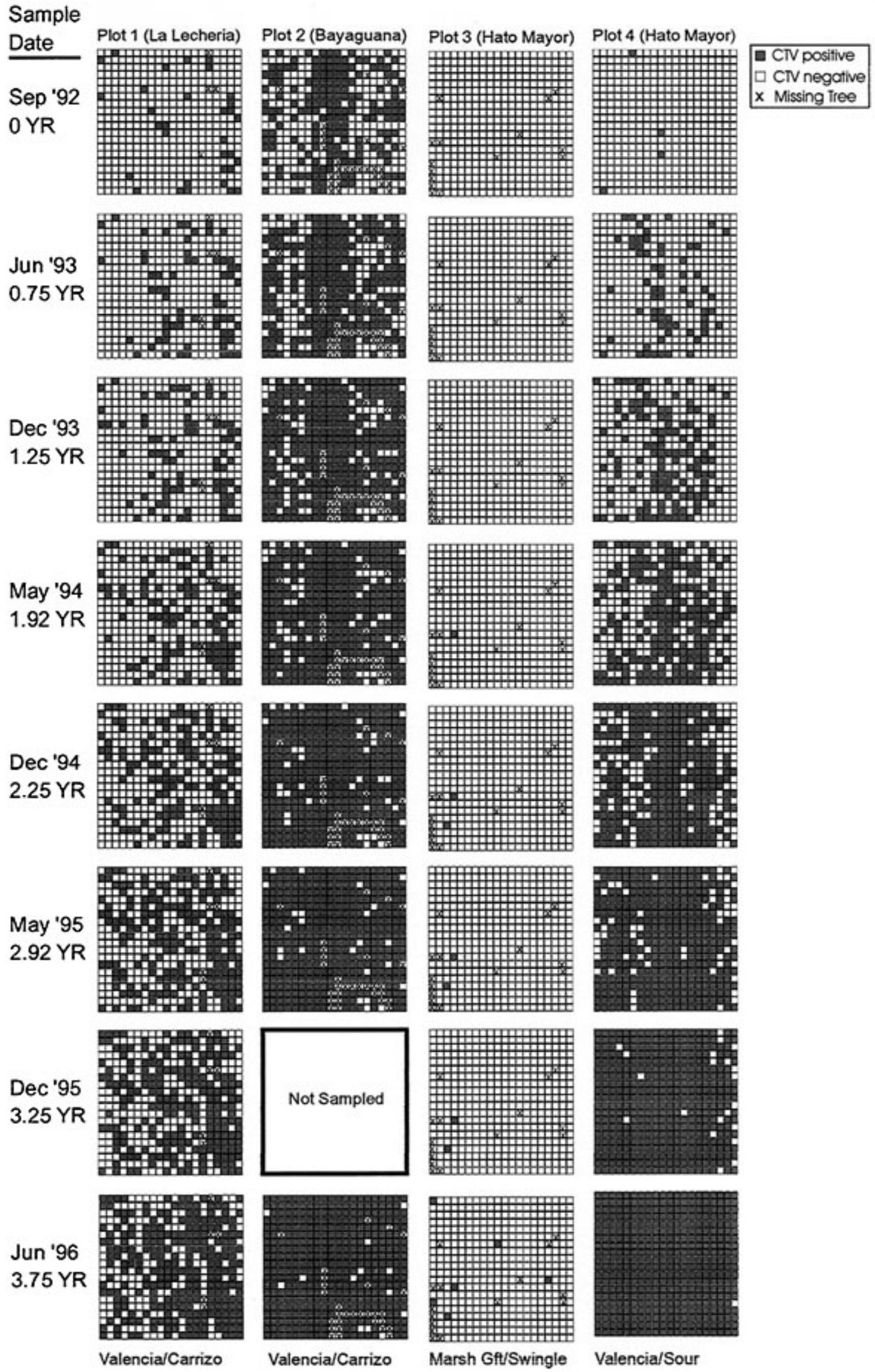

Fig. 2. Spatial patterns of citrus tristeza virus infection in four plots established in commercial citrus plantings in the Dominican Republic over time. Virus incidence for all trees in each plot was determined by enzyme-linked immunosorbent assay. 
range, plots CR4 and DR3 had too few CTV-infected trees for comparison. Similarly, plots CR2, CR3, DR2, and DR4 had too many CTV-infected trees to allow detection of aggregation during the last few assessments. The only plot for which nonrandomness was not indicated was CR3 when total CTV content was examined
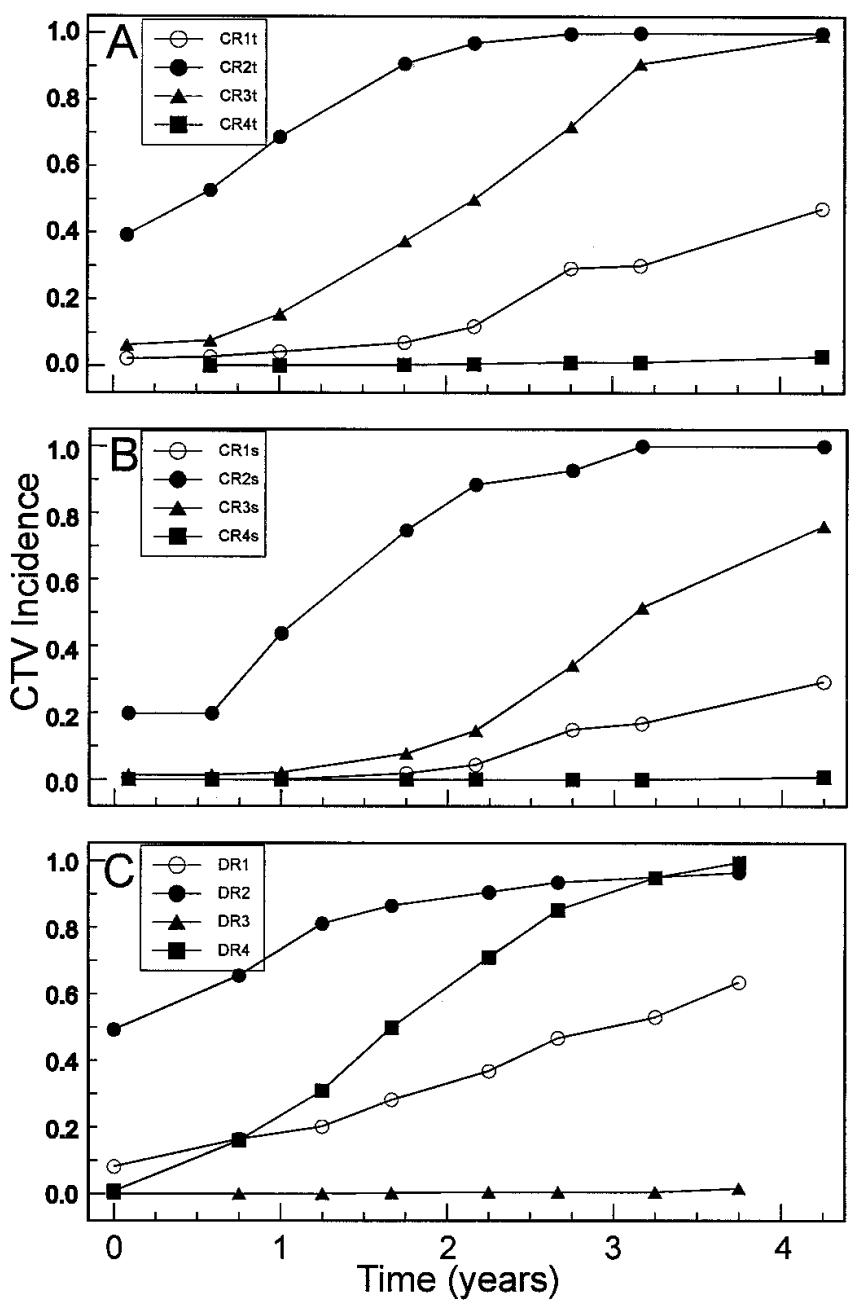

Fig. 3. Temporal increase of citrus tristeza virus (CTV) incidence in plots established in commercial citrus plantings in $\mathbf{A}$ and $\mathbf{B}$, northern Costa Rica and $\mathbf{C}$, the Dominican Republic (DR) . For Costa Rica plots, analyses are shown for A, total CTV content of all CTV isolates in each plot (CR1t, CR2t, CR3t, and CR4t) and B, specifically for severe strains of CTV in each plot (CR1s, $\mathrm{CR} 2 \mathrm{~s}, \mathrm{CR} 3 \mathrm{~s}$, and CR4s). Only mild isolate types were present in the DR plots. irrespective of isolate (i.e., mild versus severe) (Tables 3 and 4). However, when only the severe isolate component was examined, nonrandomness was indicated for most quadrat sizes when CTV incidence exceeded 0.1. For most plots on single assessment dates for which aggregation was indicated at more than one quadrat size, significant $I_{\beta}$ values were generally greater for larger quadrat sizes.

Spatial lag autocorrelation analyses results indicated that core clusters existed for most plots and quadrat sizes (Figs. 4-6). The number of significant spatial lags in the core clusters tended to increase as CTV increased from low to high incidence (0.1 to 0.8). That is, larger core clusters tended to occur later in the epidemic. At higher CTV-incidence levels, very little information was gained by the analyses. When core clusters existed, they tended to exist for all quadrat sizes tested. When trends in core cluster size existed among quadrat sizes for a specific date, smaller quadrat sizes more often corresponded to the largest core cluster sizes (Figs. 4A, 5A and $\mathrm{G}$, and $6 \mathrm{~J})$.

In the majority of cases, core clusters were complete (i.e., saturated with significant positive lags) (Figs. 4-6). However, in those cases in which core clusters were not completely saturated, strength of aggregation varied from 0.2 to 0.9 and was often associated with an asymmetry of the core cluster. When core clusters existed for 4 by 4 quadrats, the strength of aggregation was often stronger for this quadrat size than for smaller quadrat sizes (Figs. 4B, E, and $\mathrm{H} ; 5 \mathrm{~B}, \mathrm{E}$, and $\mathrm{H}$; and $6 \mathrm{~B}, \mathrm{E}$, and $\mathrm{K}$ ). For DR3, the only grapefruit plot, no CTV infection was detected in the first four assessments, and incidence at the final assay was only 0.16. For DR3, core clusters were only indicated for 2 by 3 and 4 by 4 quadrat sizes (Fig. 6G and $\mathrm{H}$ ). No trends in strength of aggregation of the core clusters were noted over time for any quadrat size by plot combination.

Row effects were detected by spatial lag autocorrelation for most plots and were most informative when CTV incidence was less than 0.8 (Figs. 4C, F, I, and L; 5C, F, I, and L; and 6C, F, I, and L). Although both within- and across-row effects were detected, when across-row effects existed, they were often stronger (Figs. 4C and L; 5C and G; and 6C, I, and L). When row effects were detected in the majority of quadrat sizes for a given assessment, row effects were often stronger for smaller quadrat sizes (Figs. 4C; 5C, F, and I; and 6C, F, and L). In the Costa Rica plots, core cluster size, strength of aggregation, and row effects were similar when analyses included all CTV isolates versus severe CTV isolates only. Reflected clusters were very rare for all proximity patterns tested and transient with respect to time.

To examine the relationship of beta-binomial analyses results of within-quadrat aggregation to spatial autocorrelation analysis (Moran's I) of among-quadrat aggregation, the results of both analyses were plotted against each other and against CTV inci-

TABLE 1. Ordinary runs analysis of citrus tristeza virus in research plots in northern Costa Rica

\begin{tabular}{|c|c|c|c|c|c|c|c|c|c|c|}
\hline \multirow[b]{2}{*}{ Plot } & \multirow[b]{2}{*}{ Direction } & \multirow[b]{2}{*}{ No. of rows tested } & \multicolumn{8}{|c|}{ Proportion of rows with aggregation ${ }^{a}$} \\
\hline & & & Oct. 92 & Apr. 93 & Sep. 93 & Jun. 94 & Nov. 94 & Jun. 95 & Nov. 95 & Dec. 96 \\
\hline \multirow{2}{*}{ CR1s } & Across & 20 & 0 & 0 & 0 & 0 & 0.05 & 0.05 & 0.05 & 0 \\
\hline & Within & 20 & 0 & 0 & 0 & 0 & 0 & 0 & 0 & 0 \\
\hline \multirow[t]{2}{*}{$\mathrm{CR} 2 \mathrm{~s}$} & Across & 20 & 0 & 0 & 0.05 & 0.10 & $-{ }^{b}$ & - & - & - \\
\hline & Within & 20 & 0.05 & 0.05 & 0.05 & 0.05 & - & - & - & - \\
\hline \multirow[t]{2}{*}{ CR3s } & Across & 20 & 0 & 0 & 0 & 0 & 0 & 0.05 & 0 & 0 \\
\hline & Within & 20 & 0 & 0 & 0 & 0 & 0 & 0.05 & 0 & 0 \\
\hline \multirow[t]{2}{*}{ CR1t } & Across & 20 & 0 & 0 & 0.05 & 0.15 & 0.10 & 0.05 & 0.10 & 0 \\
\hline & Within & 20 & 0 & 0 & 0.05 & 0.05 & 0.05 & 0.05 & 0.05 & 0 \\
\hline \multirow[t]{2}{*}{$\mathrm{CR} 2 \mathrm{t}$} & Across & 20 & 0.10 & 0.15 & 0.1 & 0 & - & - & - & - \\
\hline & Within & 20 & 0.05 & 0.05 & 0 & 0.10 & - & - & - & - \\
\hline \multirow[t]{2}{*}{ CR3t } & Across & 20 & 0 & 0.05 & 0 & 0 & 0.05 & 0.10 & 0 & - \\
\hline & Within & 14 & 0 & 0 & 0 & 0 & 0.14 & 0.07 & 0.07 & - \\
\hline \multirow[t]{2}{*}{$\mathrm{CR} 4 \mathrm{t}$} & Across & 20 & 0 & 0 & 0 & 0 & 0 & 0 & 0 & 0 \\
\hline & Within & 20 & 0 & 0 & 0 & 0 & 0 & 0 & 0 & 0 \\
\hline
\end{tabular}

a Values shown for each plot in each year are the number of rows with significant aggregation $(P=0.05)$ divided by the total number of rows tested.

$\mathrm{b}_{-}=$because of the high disease incidence, the plot data were not analyzed by ordinary runs. 
dence for each plot, quadrat size, and assessment date (Fig. 7). The results can be interpreted and placed into four categories for each plot/quadrat size/assessment date, in which (i) only the betabinomial analysis suggested aggregation, (ii) only the Moran's I analysis suggested aggregation, (iii) both beta-binomial and Moran's $I$ analyses suggested aggregation, and (iv) neither analysis suggested aggregation. The results of these analyses for each plot are shown as a function of CTV incidence (Fig. 7A to K). For individual plots, the results of the two analysis methods were generally confined within the range of 0 to 2.5 for $I_{\beta}$ and -0.1 to 0.3 for Moran's $I$. For those cases when only the beta-binomial assay suggested significant aggregation, significant $I_{\beta}$ values were often associated with the larger quadrat sizes ( 3 by 3 and 4 by 4 ), and these values were divergent and larger than the majority of $I_{\beta}$ values

TABLE 2. Ordinary runs analysis of citrus tristeza virus in research plots in the Dominican Republic

\begin{tabular}{|c|c|c|c|c|c|c|c|c|c|c|}
\hline \multirow[b]{2}{*}{ Plot } & \multirow[b]{2}{*}{ Direction } & \multirow[b]{2}{*}{ No. of rows tested } & \multicolumn{8}{|c|}{ Proportion of rows with aggregation ${ }^{a}$} \\
\hline & & & Sep. 92 & Jun. 93 & Dec. 93 & Jun. 94 & Dec. 94 & May 95 & Dec. 95 & Jun. 96 \\
\hline \multirow[t]{2}{*}{ DR1 } & Across & 20 & 0 & 0.10 & 0.05 & 0.05 & 0.10 & 0.10 & 0.05 & 0 \\
\hline & Within & 20 & 0.05 & 0.05 & 0.05 & 0 & 0 & 0 & 0.05 & 0.15 \\
\hline \multirow[t]{2}{*}{ DR2 } & Across & 20 & 0.20 & 0.10 & 0.05 & 0.05 & 0.05 & 0 & - & 0 \\
\hline & Within & 20 & 0 & 0 & 0 & 0.05 & $-\mathrm{b}$ & - & - & - \\
\hline \multirow[t]{2}{*}{ DR3 } & Across & 20 & 0 & 0 & 0 & 0 & - & - & - & - \\
\hline & Within & 20 & 0 & 0 & 0 & 0 & 0 & 0 & 0 & 0 \\
\hline \multirow[t]{2}{*}{ DR4 } & Across & 20 & 0 & 0 & 0.10 & 0.10 & 0.15 & 0.50 & 0 & 0 \\
\hline & Within & 20 & 0 & 0.10 & 0.05 & 0 & 0.10 & 0 & 0 & 0 \\
\hline
\end{tabular}

a Values shown for each plot in each year are the number of rows with significant aggregation $(P=0.05)$ divided by the total number of rows tested.

$\mathrm{b}_{-}=$because of the high disease incidence, the plot data were not analyzed by ordinary runs.

TABLE 3. Index of dispersion $\left(I_{\beta}\right)$ analyses for citrus tristeza virus (CTV) in research plots in the Dominican Republic ${ }^{\mathrm{a}}$

\begin{tabular}{|c|c|c|c|c|c|c|c|c|c|c|}
\hline \multirow[b]{2}{*}{ Plot } & \multirow[b]{2}{*}{ Quadrat size } & \multirow[b]{2}{*}{ df } & \multicolumn{8}{|c|}{ Time of assessment } \\
\hline & & & Sep. 92 & Jun. 93 & Dec. 93 & May 94 & Dec. 94 & May 95 & Dec. 95 & Jun. 96 \\
\hline \multirow{10}{*}{ DR1 } & 2 by 2 & 99 & 1.29 & 1.41 & 1.50 & 1.50 & 1.59 & 1.38 & 1.37 & 1.25 \\
\hline & & & 0.027 & 0.004 & 0.001 & 0.001 & 0.000 & 0.008 & 0.008 & 0.046 \\
\hline & 2 by 3 & 59 & 1.43 & 1.70 & 1.61 & 1.71 & 1.50 & 1.40 & 1.40 & 1.27 \\
\hline & & & 0.016 & 0.001 & 0.002 & 0.001 & 0.008 & 0.023 & 0.024 & 0.081 \\
\hline & 3 by 2 & 59 & 0.95 & 1.30 & 1.47 & 1.73 & 1.45 & 1.41 & 1.57 & 1.46 \\
\hline & & & 0.589 & 0.060 & 0.011 & 0.000 & 0.014 & 0.022 & 0.003 & 0.012 \\
\hline & 3 by 3 & 35 & 1.04 & 1.64 & 1.54 & 2.10 & 1.45 & 1.71 & 1.74 & 1.59 \\
\hline & & & 0.404 & 0.010 & 0.021 & 0.000 & 0.043 & 0.005 & 0.004 & 0.015 \\
\hline & 4 by 4 & 24 & 1.74 & 2.66 & 2.65 & 2.65 & 2.71 & 2.13 & 2.02 & 2.20 \\
\hline & & & 0.014 & 0.000 & 0.000 & 0.000 & 0.000 & 0.001 & 0.002 & 0.001 \\
\hline \multirow[t]{10}{*}{ DR2 } & 2 by 2 & 99 & 1.38 & 1.43 & 1.21 & 1.38 & 1.33 & 1.29 & $\ldots{ }^{b}$ & 1.20 \\
\hline & & & 0.007 & 0.003 & 0.076 & 0.007 & 0.016 & 0.029 & $\ldots$ & 0.085 \\
\hline & 2 by 3 & 59 & 1.70 & 1.56 & 1.35 & 1.39 & 1.16 & 1.19 & $\ldots$ & 1.01 \\
\hline & & & 0.001 & 0.004 & 0.040 & 0.026 & 0.182 & 0.153 & $\ldots$ & 0.463 \\
\hline & 3 by 2 & 59 & 1.73 & 1.94 & 1.50 & 1.61 & 1.33 & 1.31 & $\ldots$ & 1.22 \\
\hline & & & 0.000 & 0.000 & 0.008 & 0.002 & 0.046 & 0.053 & $\ldots$ & 0.119 \\
\hline & 3 by 3 & 35 & 2.22 & 2.43 & 1.96 & 1.76 & 1.20 & 1.50 & $\ldots$ & 1.00 \\
\hline & & & 0.000 & 0.000 & 0.001 & 0.004 & 0.195 & 0.028 & $\ldots$ & 0.461 \\
\hline & 4 by 4 & 24 & 2.69 & 2.18 & 1.48 & 1.57 & 1.33 & 1.17 & $\ldots$ & 1.18 \\
\hline & & & 0.000 & 0.001 & 0.060 & 0.037 & 0.130 & 0.256 & $\ldots$ & 0.247 \\
\hline \multirow[t]{10}{*}{ DR3 } & 2 by 2 & 99 & $-^{c}$ & - & - & 0.97 & 0.96 & 0.96 & 0.96 & 0.98 \\
\hline & & & - & - & - & 0.574 & 0.595 & 0.595 & 0.595 & 0.527 \\
\hline & 2 by 3 & 59 & - & - & - & 0.97 & 0.96 & 0.96 & 0.96 & 0.93 \\
\hline & & & - & - & - & 0.537 & 0.569 & 0.569 & 0.569 & 0.622 \\
\hline & 3 by 2 & 59 & - & - & - & 0.97 & 1.17 & 1.17 & 1.17 & 0.94 \\
\hline & & & - & - & - & 0.543 & 0.177 & 0.177 & 0.177 & 0.601 \\
\hline & 3 by 3 & 35 & - & - & - & 0.97 & 1.17 & 1.17 & 1.17 & 0.91 \\
\hline & & & - & - & - & 0.511 & 0.224 & 0.224 & 0.224 & 0.627 \\
\hline & 4 by 4 & 24 & - & - & - & 1.10 & 1.19 & 1.19 & 1.19 & 1.26 \\
\hline & & & - & - & - & 0.330 & 0.238 & 0.238 & 0.238 & 0.173 \\
\hline \multirow[t]{10}{*}{ DR4 } & 2 by 2 & 99 & 0.99 & 1.45 & 1.37 & 1.54 & 1.44 & 1.25 & 1.19 & 0.99 \\
\hline & & & 0.517 & 0.002 & 0.008 & 0.000 & 0.003 & 0.047 & 0.092 & 0.495 \\
\hline & 2 by 3 & 59 & 0.97 & 1.80 & 1.61 & 1.94 & 1.99 & 1.45 & 1.39 & 0.99 \\
\hline & & & 0.532 & 0.000 & 0.002 & 0.000 & 0.000 & 0.013 & 0.025 & 0.550 \\
\hline & 3 by 2 & 59 & 0.97 & 1.43 & 1.44 & 1.48 & 1.36 & 1.26 & 1.29 & 0.99 \\
\hline & & & 0.532 & 0.018 & 0.015 & 0.010 & 0.034 & 0.088 & 0.066 & 0.500 \\
\hline & 3 by 3 & 35 & 0.95 & 1.64 & 1.69 & 1.91 & 1.64 & 1.39 & 1.50 & 0.98 \\
\hline & & & 0.550 & 0.010 & 0.006 & 0.001 & 0.010 & 0.063 & 0.029 & 0.506 \\
\hline & 4 by 4 & 24 & 0.92 & 2.56 & 2.98 & 3.17 & 3.66 & 2.56 & 2.56 & 0.96 \\
\hline & & & 0.569 & 0.000 & 0.000 & 0.000 & 0.000 & 0.000 & 0.000 & 0.513 \\
\hline
\end{tabular}

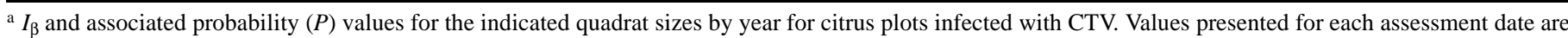
$I_{\beta}$ (= observed variance/binomial variance) and $P$ (= significance probability). $P$ values were calculated by comparison of df $\times I_{\beta}$ with the chi-squared distribution. Values of $I_{\beta}$ not significantly different from $1(0.95>P>0.05)$ indicate that the pattern of diseased trees is indistinguishable from random. A large $(>1) I_{\beta}$ and a small $P(\leq 0.05)$ suggest rejection of $H_{0}$ (random pattern of virus-infected trees) in favor of $H_{1}$ (aggregated pattern of virus-infected trees). Incidence of individual CTV-positive trees was determined by enzyme-linked immunosorbent assay using a mixture of two generic monoclonal antibodies. b $\ldots=$ plot not sampled on this date.

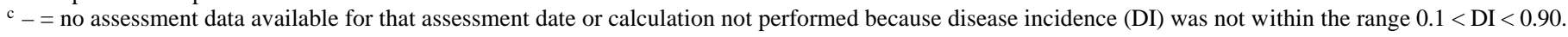




\begin{tabular}{|c|c|c|c|c|c|c|c|c|c|c|}
\hline \multirow[b]{2}{*}{ Plot } & \multirow[b]{2}{*}{ Quadrat size } & \multirow[b]{2}{*}{$\mathrm{df}$} & \multicolumn{8}{|c|}{ Time of assessment } \\
\hline & & & Oct. 92 & Apr. 93 & Sep. 93 & Jun. 94 & Nov. 94 & Jun. 95 & Nov. 95 & Dec. 96 \\
\hline \multicolumn{11}{|c|}{ All CTV isolates mild + severe } \\
\hline \multirow[t]{10}{*}{ CR1 } & 2 by 2 & 99 & 1.18 & 1.11 & 1.64 & 1.49 & 1.68 & 1.48 & 1.50 & 1.50 \\
\hline & & & 0.112 & 0.216 & 0.000 & 0.001 & 0.000 & 0.001 & 0.001 & 0.001 \\
\hline & 2 by 3 & 59 & 1.33 & 1.18 & 2.21 & 1.74 & 1.90 & 1.94 & 1.99 & 1.71 \\
\hline & & & 0.047 & 0.162 & 0.000 & 0.000 & 0.000 & 0.000 & 0.000 & 0.001 \\
\hline & 3 by 2 & 59 & 1.60 & 1.60 & 1.60 & 1.49 & 1.41 & 1.46 & 1.76 & 1.68 \\
\hline & & & 0.002 & 0.002 & 0.002 & 0.009 & 0.020 & 0.012 & 0.000 & 0.001 \\
\hline & 3 by 3 & 35 & 1.61 & 1.61 & 1.61 & 1.11 & 1.21 & 1.90 & 2.38 & 2.11 \\
\hline & & & 0.013 & 0.013 & 0.013 & 0.304 & 0.181 & 0.001 & 0.000 & 0.000 \\
\hline & 4 by 4 & 24 & 1.26 & 1.07 & 2.25 & 2.75 & 2.43 & 2.63 & 3.02 & 2.40 \\
\hline & & & 0.176 & 0.370 & 0.000 & 0.000 & 0.000 & 0.000 & 0.000 & 0.000 \\
\hline \multirow[t]{10}{*}{ CR2 } & 2 by 2 & 99 & 1.15 & 0.95 & 1.18 & 1.24 & 0.95 & 1.00 & $\ldots{ }^{b}$ & $\ldots$ \\
\hline & & & 0.147 & 0.621 & 0.102 & 0.051 & 0.620 & 0.488 & $\ldots$ & $\ldots$ \\
\hline & 2 by 3 & 59 & 1.02 & 0.88 & 1.15 & 1.41 & 0.91 & 1.00 & $\ldots$ & $\ldots$ \\
\hline & & & 0.439 & 0.730 & 0.207 & 0.020 & 0.676 & 0.482 & $\ldots$ & $\ldots$ \\
\hline & 3 by 2 & 59 & 1.08 & 0.98 & 1.30 & 1.24 & 0.87 & 1.00 & $\ldots$ & $\ldots$ \\
\hline & & & 0.306 & 0.527 & 0.062 & 0.100 & 0.751 & 0.482 & $\ldots$ & $\ldots$ \\
\hline & 3 by 3 & 35 & 0.86 & 0.81 & 1.11 & 1.33 & 0.82 & 1.00 & $\ldots$ & $\ldots$ \\
\hline & & & 0.699 & 0.782 & 0.304 & 0.091 & 0.771 & 0.474 & $\ldots$ & $\ldots$ \\
\hline & 4 by 4 & 24 & 1.47 & 1.32 & 1.58 & 1.85 & 1.29 & 1.00 & $\ldots$ & $\ldots$ \\
\hline & & & 0.063 & 0.136 & 0.036 & 0.007 & 0.156 & 0.465 & $\ldots$ & $\ldots$ \\
\hline CR3 & 2 by 2 & 69 & 1.19 & 1.28 & 1.10 & 1.20 & 1.12 & 1.20 & 0.79 & $-^{\mathrm{c}}$ \\
\hline & & & 0.134 & 0.058 & 0.265 & 0.121 & 0.230 & 0.124 & 0.896 & - \\
\hline & 2 by 3 & 41 & 1.21 & 1.22 & 0.98 & 0.98 & 1.00 & 1.32 & 0.90 & - \\
\hline & & & 0.170 & 0.154 & 0.513 & 0.501 & 0.462 & 0.085 & 0.645 & - \\
\hline & 3 by 2 & 39 & 1.26 & 1.55 & 1.40 & 1.16 & 1.05 & 0.96 & 0.77 & - \\
\hline & & & 0.131 & 0.015 & 0.050 & 0.229 & 0.380 & 0.540 & 0.848 & - \\
\hline & 3 by 3 & 23 & 1.38 & 1.47 & 1.02 & 0.93 & 0.79 & 1.07 & 0.61 & - \\
\hline & & & 0.108 & 0.069 & 0.440 & 0.556 & 0.755 & 0.376 & 0.929 & - \\
\hline & 4 by 4 & 14 & 0.93 & 1.13 & 1.54 & 1.06 & 1.18 & 1.55 & 0.82 & - \\
\hline & & & 0.520 & 0.327 & 0.089 & 0.390 & 0.280 & 0.084 & 0.643 & - \\
\hline CR4 & 2 by 2 & 99 & - & - & - & 1.00 & 0.99 & 0.97 & -0.97 & 0.92 \\
\hline & & & - & - & - & 0.481 & 0.503 & 0.553 & 0.553 & 0.704 \\
\hline & 2 by 3 & 59 & - & - & - & 1.00 & 0.99 & 1.01 & 1.01 & 0.87 \\
\hline & & & - & - & - & 0.476 & 0.507 & 0.464 & 0.464 & 0.751 \\
\hline & 3 by 2 & 59 & - & - & - & 1.00 & 0.99 & 0.95 & 0.95 & 0.87 \\
\hline & & & - & - & - & 0.476 & 0.507 & 0.576 & 0.576 & 0.759 \\
\hline & 3 by 3 & 35 & - & - & - & 1.00 & 0.97 & 0.95 & 0.95 & 1.19 \\
\hline & & & - & - & - & 0.468 & 0.511 & 0.550 & 0.550 & 0.199 \\
\hline & 4 by 4 & 24 & - & - & - & 1.00 & 0.96 & 1.42 & 1.42 & 1.01 \\
\hline & & & - & - & - & 0.462 & 0.517 & 0.085 & 0.085 & 0.451 \\
\hline Severe & & & & & & & & & & \\
\hline CR2 & 2 by 2 & 99 & - & - & - & 1.26 & 1.11 & 1.26 & 1.19 & 1.21 \\
\hline & & & - & - & - & 0.043 & 0.213 & 0.040 & 0.095 & 0.073 \\
\hline & 2 by 3 & 59 & - & - & - & 1.20 & 1.22 & 1.48 & 1.33 & 1.38 \\
\hline & & & - & - & - & 0.135 & 0.120 & 0.009 & 0.044 & 0.029 \\
\hline & 3 by 2 & 59 & - & - & - & 0.95 & 0.84 & 0.94 & 1.26 & 1.33 \\
\hline & & & - & - & - & 0.576 & 0.804 & 0.599 & 0.083 & 0.045 \\
\hline & 3 by 3 & 35 & - & - & - & 0.89 & 0.98 & 1.23 & 1.56 & 1.64 \\
\hline & & & - & - & - & 0.649 & 0.503 & 0.164 & 0.018 & 0.010 \\
\hline & 4 by 4 & 24 & - & - & - & 1.64 & 1.97 & 1.91 & 1.78 & 1.59 \\
\hline & & & - & - & - & 0.025 & 0.003 & 0.005 & 0.011 & 0.034 \\
\hline $\mathrm{CR} 2$ & 2 by 2 & 99 & 1.16 & 1.16 & 1.30 & 1.57 & 1.37 & 1.15 & - & - \\
\hline & & & 0.137 & 0.137 & 0.024 & 0.000 & 0.009 & 0.141 & - & - \\
\hline & 2 by 3 & 59 & 1.26 & 1.26 & 1.21 & 1.60 & 1.52 & 1.47 & - & - \\
\hline & & & 0.083 & 0.083 & 0.129 & 0.002 & 0.006 & 0.011 & - & - \\
\hline & 3 by 2 & 59 & 1.39 & 1.39 & 1.74 & 1.81 & 1.73 & 1.29 & - & - \\
\hline & & & 0.026 & 0.026 & 0.000 & 0.000 & 0.000 & 0.063 & - & - \\
\hline & 3 by 3 & 35 & 1.09 & 1.09 & 1.38 & 2.16 & 1.91 & 1.84 & - & - \\
\hline & & & 0.335 & 0.335 & 0.065 & 0.000 & 0.001 & 0.002 & - & - \\
\hline & 4 by 4 & 24 & 1.67 & 1.67 & 1.67 & 3.27 & 2.57 & 2.37 & - & - \\
\hline & & & 0.022 & 0.022 & 0.021 & 0.000 & 0.000 & 0.000 & - & - \\
\hline CR3 & 2 by 2 & 99 & 0.97 & 0.97 & 0.99 & 1.25 & 1.11 & 1.06 & 1.36 & 1.57 \\
\hline & & & 0.575 & 0.575 & 0.521 & 0.045 & 0.209 & 0.313 & 0.010 & 0.000 \\
\hline & 2 by 3 & 59 & 0.98 & 0.98 & 0.95 & 1.34 & 1.22 & 1.18 & 1.79 & 2.11 \\
\hline & & & 0.518 & 0.518 & 0.591 & 0.043 & 0.117 & 0.160 & 0.000 & 0.000 \\
\hline & 3 by 2 & 59 & 0.94 & 0.94 & 0.90 & 1.37 & 1.37 & 1.29 & 1.23 & 1.79 \\
\hline & & & 0.607 & 0.607 & 0.700 & 0.032 & 0.031 & 0.066 & 0.108 & 0.000 \\
\hline & 3 by 3 & 35 & 0.92 & 0.92 & 1.09 & 1.80 & 1.40 & 1.73 & 1.58 & 2.31 \\
\hline & & & 0.605 & 0.605 & 0.326 & 0.003 & 0.059 & 0.005 & 0.016 & 0.000 \\
\hline & 4 by 4 & 24 & 1.26 & 1.26 & 0.99 & 2.31 & 1.58 & 1.57 & 2.80 & 4.47 \\
\hline & & & 0.177 & 0.177 & 0.474 & 0.000 & 0.036 & 0.038 & 0.000 & 0.000 \\
\hline
\end{tabular}

$\mathrm{CR} 4$

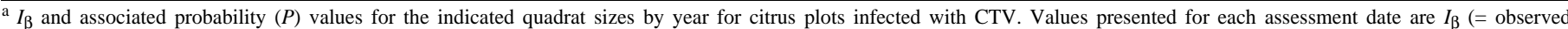
variance/binomial variance) and $P$ (= significance probability). $P$ values were calculated by comparison of df $\times \mathrm{I}_{\beta}$ with the chi-squared distribution. Values of $I_{\beta}$ not significantly different from $1(0.95>P>0.05)$ indicate that the pattern of diseased trees is indistinguishable from random. A large $(>1) I_{\beta}$ and a small $P(\leq 0.05)$ suggest rejection of $H_{0}($ random pattern of virus-infected trees) in favor of $H_{1}$ (aggregated pattern of virus-infected trees). For total CTV content in the plots, incidence of individual CTV-positive trees was determined by enzyme-linked immunosorbent assay using a mixture of two generic monoclonal antibodies, and incidence of severe isolates of CTV was based on determination of infection by a single strain-selective monoclonal antibody, MCA13.

b $\ldots=$ plot not sampled this date.

$\mathrm{c}_{-}=$no assessment data available for that assessment date or calculation not performed because disease incidence (DI) was not within the range $0.1<$ DI $<0.90$.

d No severe disease. 
associated with other assays (Fig. 7B, D-F, J, and K; white circles and squares). When only Moran's $I$ assays indicated aggregation, the Moran's $I$ values were generally within the -0.1 to 0.3 range, but were also often associated with larger quadrat sizes (Fig. 7F, $\mathrm{G}$, I, and J; gray circles and squares).

This relationship between within- and among-quadrat assays was also examined by ignoring the relative values of the indices, considering only significant values, and plotting the results from all plots and quadrat sizes together (Fig. 8). Significant $I_{\beta}$ (Fig. 8A and D) and Moran's I values (Fig. 8B and E) existed for all quadrat sizes tested for both Costa Rica and Dominican Republic plots. The number of cases for which both indices were significant was much fewer (Fig. 8C and F). The quadrat size most commonly associated with significance for both indices was 2 by 2 , and the quadrat size least commonly associated with significance for both indices was 3 by 3 (Fig. 8C and F). For the Dominican Republic plots, quadrat sizes 3 by 2,3 by 3 , and 4 by 4 , for which significance existed for both indices, were associated almost exclusively with individual plots DR2, DR4, and DR3, respectively (Fig. 8F). For the Costa Rica plots, quadrat size 3 by 3 , for which significance existed for both within- and among-quadrat size assays, was associated almost exclusively with plot CR2 severe (Fig. 8C).

\section{DISCUSSION}

The main goals of the study were to examine the spatio-temporal relationships of CTV-infected trees in the presence of the brown citrus aphid, T. citricida, including the relationship of newly CTVinfected trees to previous infections; to test for directionality of
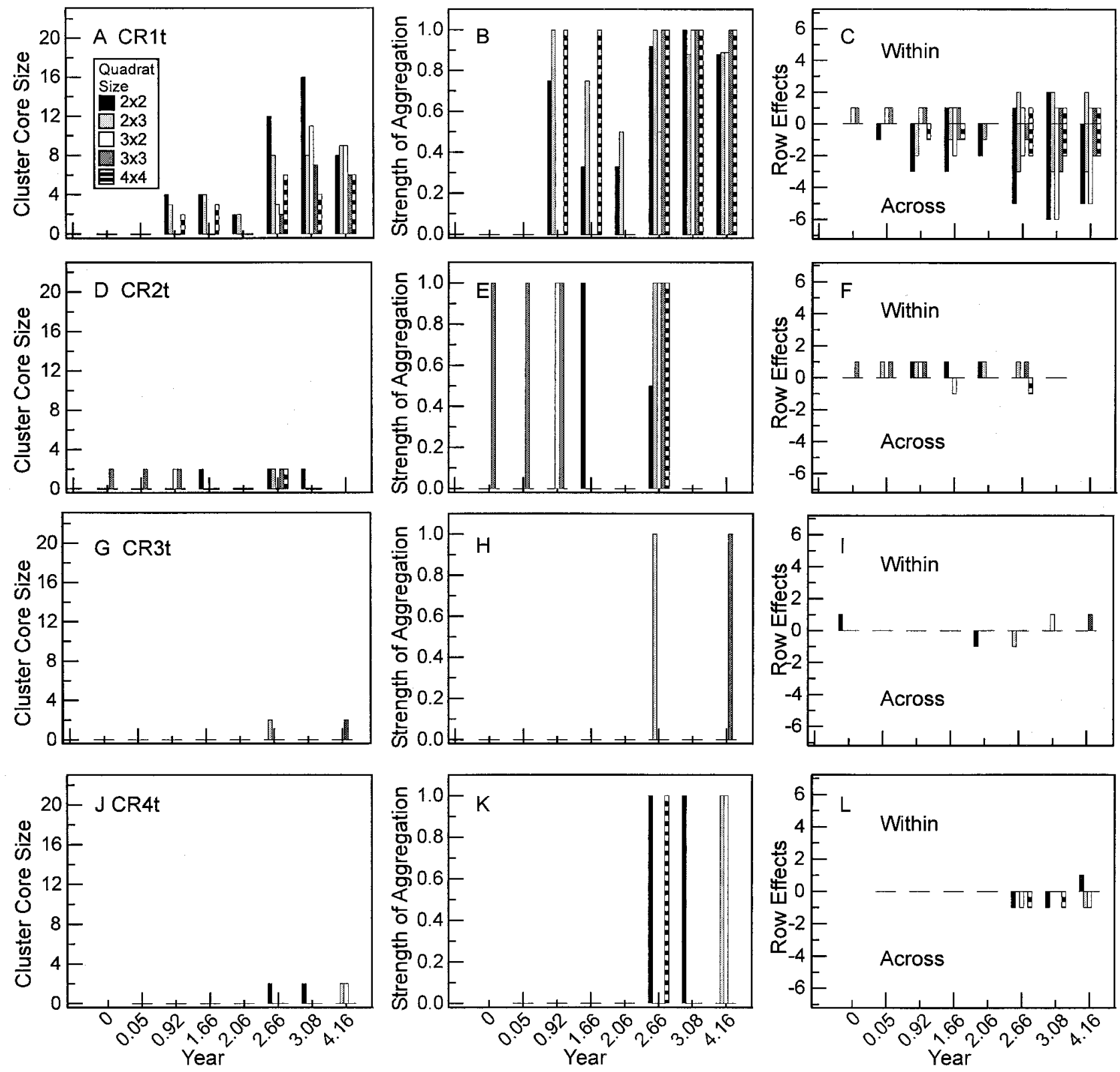

Fig. 4. Spatial autocorrelation analysis of total citrus tristeza virus in plots in commercial citrus plantings in northern Costa Rica. Plots studied were A-C, CR1t; D-F, CR2t; G-I, CR3t; and J-L, CR4t. A, D, G, and J, Core cluster size (i.e., the number of significant lag distance positions contiguous with the origin of the autocorrelation proximity pattern that form a discrete group); $\mathbf{B}, \mathbf{E}, \mathbf{H}$, and $\mathbf{K}$, strength of aggregation (i.e., an estimate of the density of the core cluster as the proportion of significant lag distance positions within the autocorrelation proximity pattern that are circumscribed by the outer row and column of the core cluster); and $\mathbf{C , ~} \mathbf{F}, \mathbf{I}$, and $\mathbf{L}$, row effects (i.e., the number of significant lag distance positions within the first row [within] or within the first column [across] of the autocorrelation proximity pattern that are contiguous with the origin of the proximity pattern). The horizontal axis represents the eight assessment dates over 4 years. For each assessment date, the various quadrat sizes are represented as response bars with fill patterns indicated in the legend insert in $\mathbf{A}$. 
CTV spread; and to examine the size, shape, and change of patterns of CTV-infected trees. In a previous study, these relationships were characterized for the CTV pathosystem in Spain, where $T$. citricida was absent and the predominant CTV vector was the melon aphid, A. gossypii (20,21). Similarly, the CTV pathosystems in Florida and California have been examined and temporal and spatial spread found to be consistent with that demonstrated in Spain (22). The melon aphid has historically been the predominant CTV vector in citrus-growing areas in Florida, Texas, and California $(15,46)$.

Temporal analyses. Data from plots in orange plantings in Costa Rica and the Dominican Republic were adequately represented by the Gompertz model as expected from the shape of the CTV progress curves. For orange plots in which CTV incidence was low ( 0.05) at the beginning of the study, using the Gompertz model, incidence was estimated to increase to asymptotic levels in 3.5 to 6.0 years. This is in contrast to data obtained from Spain and Florida, where $A$. gossypii is the primary vector and where the same increase was estimated to occur in 8 to 14 years $(20-22$; T. R. Gottwald, unpublished data). Scion and rootstock combinations and horticultural conditions were similar among all these studies. Therefore, the more rapid temporal increase of CTV measured in Costa Rica and the Dominican Republic can be attributed primarily to the large populations of $T$. citricida that developed, combined with the greater transmission efficiency associated with $T$. citricida compared with pathosystems in which this vector is absent, such as those pathosystems characterized by A. gossypii as the primary vector. The single grapefruit plot studied, DR3, did not become infected until late in the second year of the study, after which CTV incidence progressed slowly. The lower rate of infec-
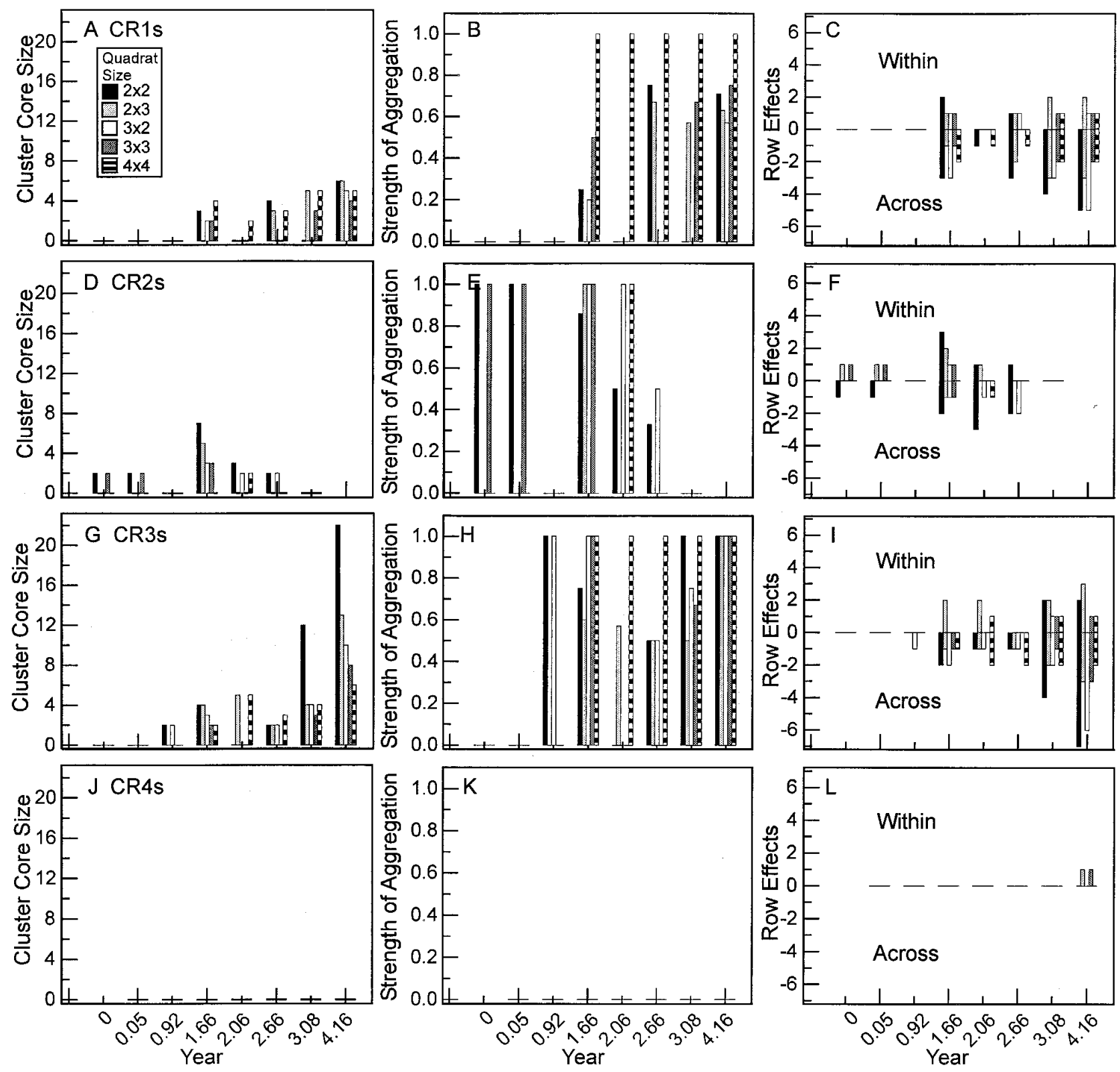

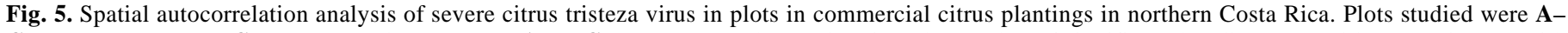

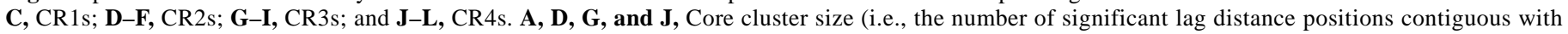

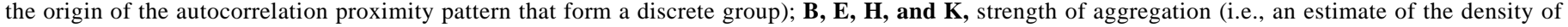

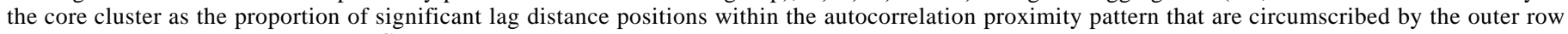

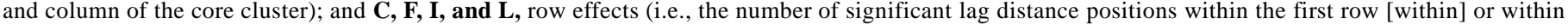

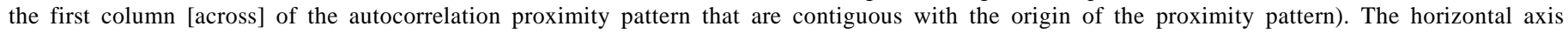

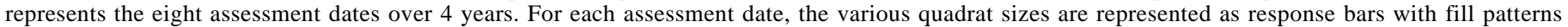
indicated in the legend insert in $\mathbf{A}$. 
tion in DR3 was apparently associated with the grapefruit scion, since plot DR3 was of similar age to the DR4 orange plot, which was located in the same vicinity and had the most rapid increase of CTV incidence for all plots examined in the study. Aphid exposure was apparently similar in both plots, and colonies of T. citricida were noted in both plots at about the same time. The slow temporal increase of CTV incidence in grapefruit compared with sweet orange has been noted previously (21). This may represent a differential susceptibility of some grapefruit cultivars to some naturally transmitted CTV isolates. The mechanism is unknown and grapefruit trees, once infected, show CTV titers similar to sweet orange (S. M. Garnsey, unpublished data). Due to the relatively slow CTV epidemics in grapefruit, examination of temporal increase of CTV in this type of citrus will require longer multi-year studies that are beyond the scope of the current study.
Spatial analyses. Spatial relationships of CTV-infected trees were examined at three distinct spatial scales: (i) immediately adjacent trees within and across rows, (ii) within quadrats (groups of contiguous trees) of various size, and (iii) among quadrats that were either contiguous or spaced over longer distances in a larger spatial matrix. For the Costa Rica and Dominican Republic plots, randomness of CTV incidence among immediately adjacent trees within and across rows generally was indicated for the majority of plots and assessment periods by ordinary runs. These findings indicated that the virus status of CTV-positive trees was independent of the virus status of adjacent trees. These findings are consistent with the results of studies in which A. gossypii was the predominant vector (21). However, this general lack of similarity of CTV status among immediately adjacent trees is not indicative of a lack of spatial processes, which might occur over longer dis-
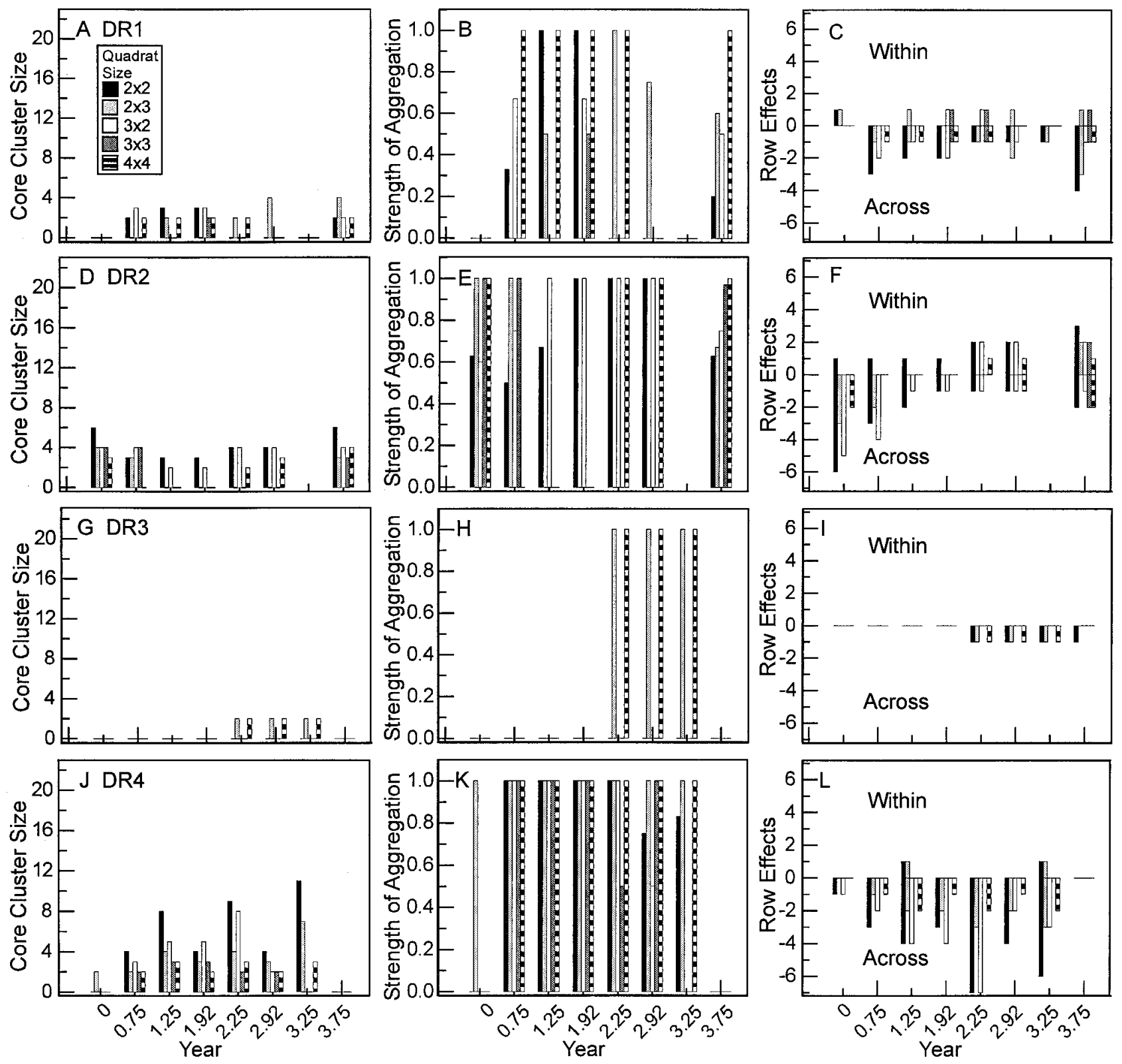

Fig. 6. Spatial autocorrelation analysis of total citrus tristeza virus in plots in commercial citrus plantings in the Dominican Republic. Plots studied were A-C, DR1; D-F, DR2; G-I, DR3; and J-L, DR4. A, D, G, and J, Core cluster size (i.e., the number of significant lag distance positions contiguous with the origin of the autocorrelation proximity pattern that form a discrete group); $\mathbf{B}, \mathbf{E}, \mathbf{H}$, and $\mathbf{K}$, strength of aggregation (i.e., an estimate of the density of the core cluster as the proportion of significant lag distance positions within the autocorrelation proximity pattern that are circumscribed by the outer row and column of the core cluster); and $\mathbf{C , ~ F , ~ I , ~ a n d ~} \mathbf{L}$, row effects (i.e., the number of significant lag distance positions within the first row [within] or within the first column [across] of the autocorrelation proximity pattern that are contiguous with the origin of the proximity pattern). The horizontal axis represents the eight assessment dates over 4 years. For each assessment date, the various quadrat sizes are represented as response bars with fill patterns indicated in the legend insert in $\mathbf{A}$. 
tances. To investigate longer-distance relationships, other spatial scales were examined.

Beta-binomial spatial analyses indicated a prevalence of nonrandom spatial patterns for data partitioned into all quadrat sizes tested. Generally, when a lack of randomness was indicated for one quadrat size, the same was indicated for other quadrat sizes tested as well. Randomness was indicated for only one plot, CR3, when data for all CTV isolates was examined. However, when the data for only the severe CTV isolate distribution was examined from plot CR3, nonrandomness was indicated. Unfortunately, the mild CTV isolate could not be examined independently, because the monoclonal probes used could not differentiate the presence of the mild isolate in a coinfected tree. The six rows on the western edge of plot CR3 were planted with trees infected with mild CTV
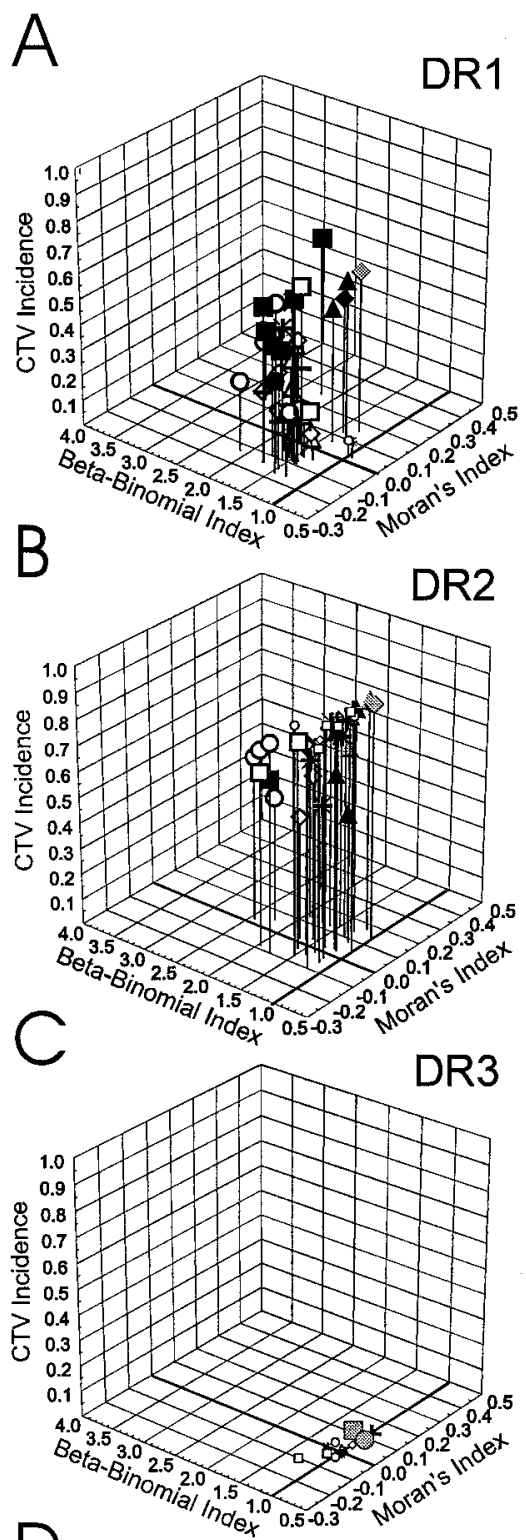

D

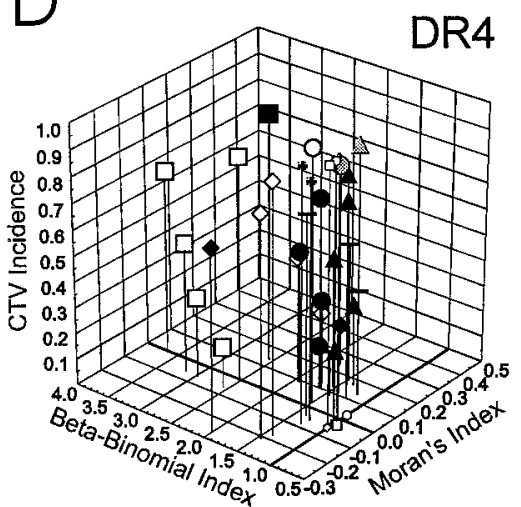

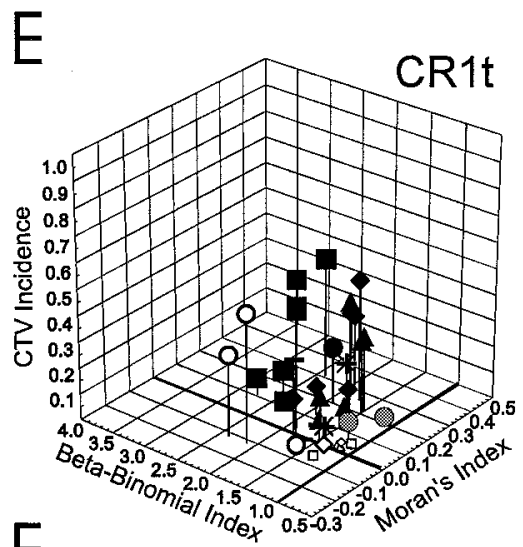
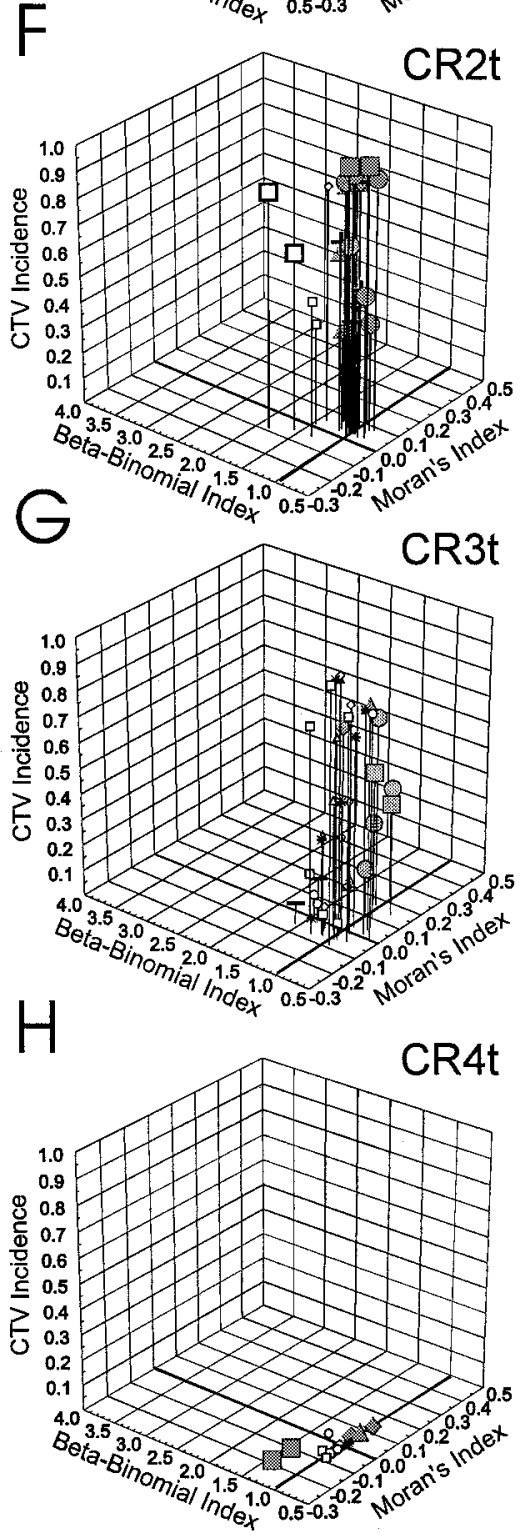
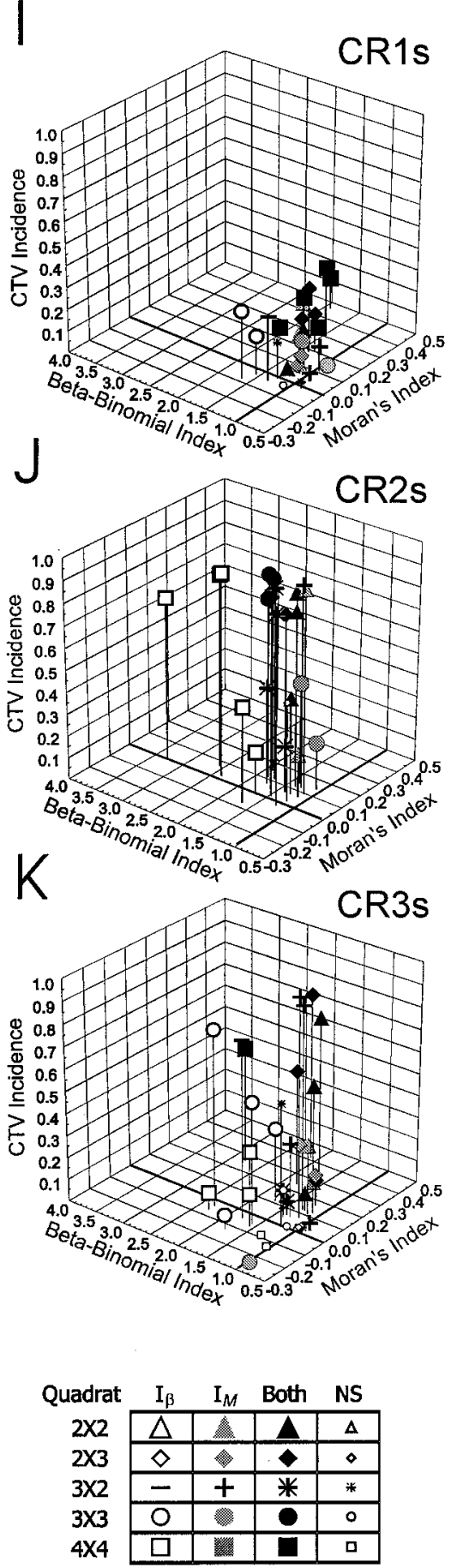

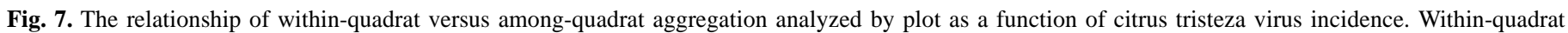
aggregation was assumed if the beta-binomial index $I_{\beta}>1.0$ at $P=0.05$. Among-quadrat aggregation was assumed if the Moran's $I>0.0$ at $P=0.05$. 
and, therefore, were eliminated from the analysis based on all CTV isolates so as not to force detection of nonrandomness. Thus, the smaller size of the plot resulted in fewer quadrats to test, which may have adversely affected the detection of nonrandomness. Alternatively, the presence of two isolates was ignored when testing the spatial pattern based on all isolates of CTV. Such an analysis based on all CTV isolates is not unrealistic. It is common to use monoclonal mixtures or polyclonal antibodies for general detection of CTV in the field to measure total CTV content and, therefore, ignore discrimination of individual isolates. The spatial characterization of the mild CTV isolates in plot CR3 was not determined independently; however, the combination incidence of the two isolates, monitored without discrimination, leads to an apparent random spatial pattern at the within-quadrat level, even though the severe CTV isolate was nonrandomly distributed. With this exception for CR3 as noted, the general presence of nonrandom spatial patterns within quadrats indicated a general, local relationship among CTV-infected trees. This relationship was usually stronger for larger quadrat sizes, which is consistent with ordinary runs results and indicates a lack of similarity of
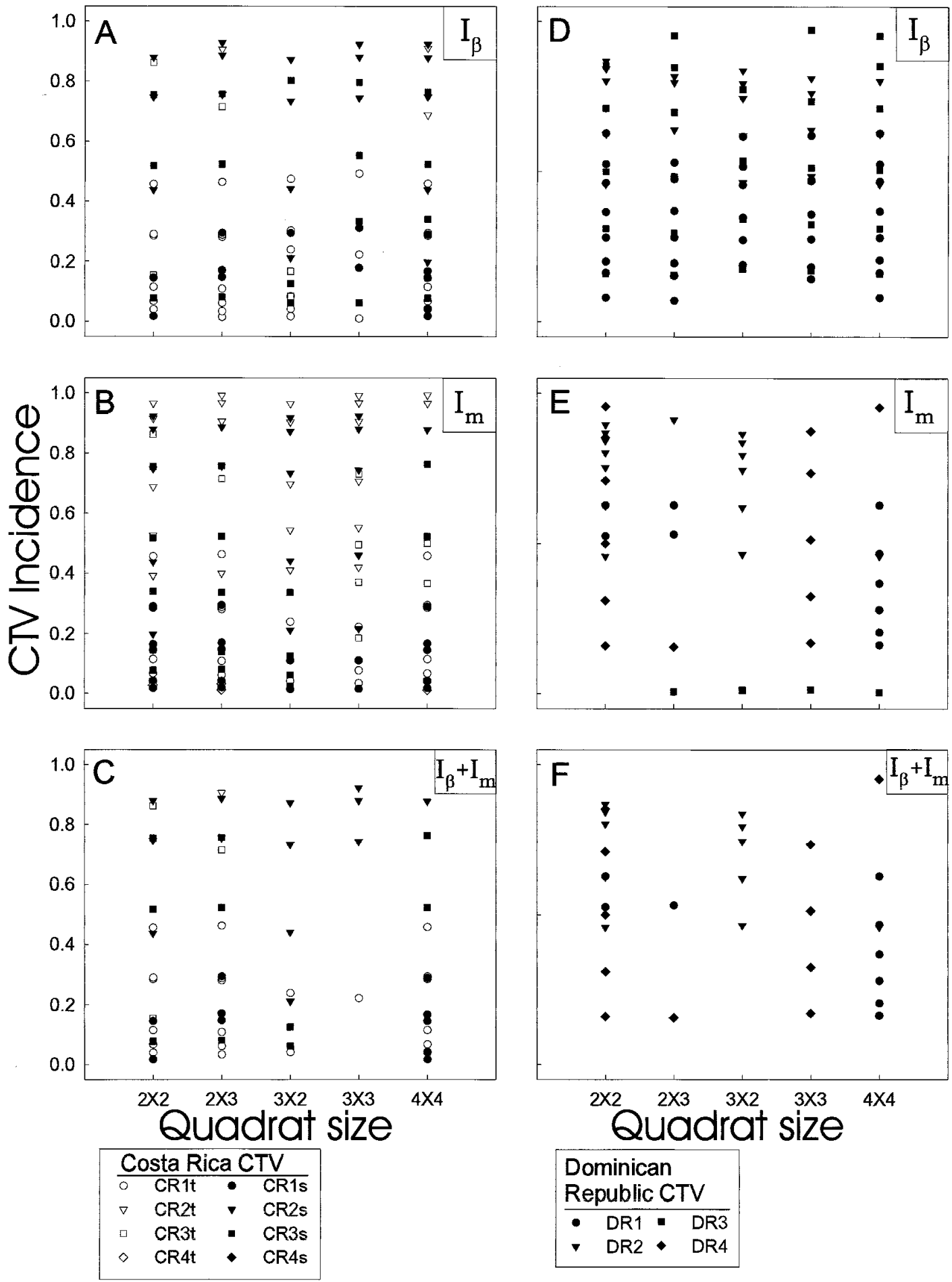

Fig. 8. Scatter plot representation of the significant beta-binomial index and Moran's $I$ tests for spatial aggregation. A and D, Quadrat sizes and citrus tristeza virus (CTV) incidence levels for which within-quadrat aggregation was indicated by beta-binomial index $I_{\beta}>1.0$ at $P=0.05$. B and E, Quadrat sizes and CTV incidence levels for which among-quadrat aggregation was indicated by spatial autocorrelation measured as Moran's $I>0.0$ at $P=0.05$. C and F, Quadrat sizes and CTV incidence levels for which both $I_{\beta}$ and Moran's $I$ indices suggested aggregation. 
virus status between immediately adjacent trees within and across rows. This means that a significant local relationship of CTV status within quadrats is indicated, but does not necessarily exist among adjacent neighboring trees, with the following caveat.

For beta-binomial analyses, aggregation of CTV-positive trees was indicated for all quadrat sizes, and the highest $I_{\beta}$ values existed for larger quadrat sizes. One apparent discrepancy does exist between the results of ordinary runs analyses and that of the betabinomial analyses at the 2 by 2 -quadrat size. Although ordinary runs analyses indicated a predominance of random spatial patterns for immediately adjacent trees, the beta-binomial analyses of 2 by 2 quadrats, which also examines the spatial patterns among immediately adjacent trees, indicated a prevalence of nonrandom patterns. Although one might conclude that the results of these two methods are contradictory, further examination will provide evidence that this is not the case. Whereas ordinary runs is a onedimensional spatial analysis and only examines the data structure either within or across rows, the beta-binomial analysis of 2 by 2 quadrats simultaneously evaluates the data structure collectively, both within and across rows as well as at diagonals. Therefore, the lack of a random pattern can be indicated when the data are evaluated only in one direction (i.e., within or across rows), and yet an aggregated spatial pattern can exist when within-row, across-row, and diagonal comparisons are considered collectively to determine a departure from randomness. These findings were interpreted to indicate a similarity of CTV status within local areas of influence. That is, even though CTV-positive trees do not often influence the CTV status of their immediately adjacent neighbors within or across rows, they do influence the CTV status within areas circumscribed by groups of $4,6,9$, and 16 trees, as defined by 2 by 2,2 by 3,3 by 2,3 by 3 , and 4 by 4 quadrat sizes. The 2 by 3 and 3 by 2 quadrat sizes were used to examine whether or not a directional orientation to aggregation existed; however, no directional prevalence was indicated.

The final spatial scale investigated was the association among quadrats of similar CTV status as determined by spatial autocorrelation. At this spatial scale, autocorrelation analyses were examined for longer-distance spatial relationships. The existence of core clusters was indicative of a relationship of CTV status among immediately adjacent quadrats. The strength of aggregation values at or near 1.0 for many dates and quadrat sizes when core clusters existed can be interpreted as a strong general association among quadrats within a given area of influence. For the smallest quadrat size tested ( 2 by 2 ), this relationship often extended to two to four lag positions within row, across row, and at a diagonal. For larger quadrat sizes, for the same plots and assessment dates, this relationship also existed but was less extensive, as expected, and indicated approximately the same area of influence of similar CTV status. Thus, the area of influence of like-CTV status had a radius of four to eight tree spacings. This area of influence can be thought of as the area for local CTV spread. In some cases, the core cluster was more extensive across rows than within rows, and indicated that an elliptical rather than a circular area of influence existed.

The general lack of reflected clusters of significant positive lags indicated that relationships among lags discontinuous from the core cluster were rare. Thus, longer-distance discontinuous relationships among quadrats of similar status were not detected. However, this may be related to the limited plot size. Plot size was largely dictated by resources (i.e., the number of samples that could be collected and processed via ELISA). However, had larger plot sizes been used, it is possible that longer-distance relationships may or may not have been detected. Such relationships need to be investigated in the future, but will be costly in time and resources and are beyond the scope of this study.

With the exception of the beta-binomial analysis of plot CR3, there were no distinctions detected between spatial patterns for total virus content of all CTV isolates versus those associated with severe CTV isolates only, when examined by ordinary runs, beta-binomial, or spatial autocorrelation analyses. A previous study indicated that the mild and severe CTV isolates in the Costa Rica plots were codispersed independently without apparent competition (23).

Relationship of spatio-temporal patterns of CTV to aphid biology. The 1995 introduction of T. citricida into south Florida and its northward spread through the state has raised concern for the citrus industry of Florida. This concern is mainly due to the CTV transmission efficiency of the brown citrus aphid, which has been demonstrated to be up to 25 times more effective for CTV transmission than the next most efficient vector, A. gossypii (45). Findings from this study provide insight into the underlying processes of CTV spread in the presence of $T$. citricida. With the exception of the area in which plot CR3 was located, there was no indication that the remaining citrus plantings were established with CTV-infected nursery trees; even if this was the case, CTVinfected trees were not planted in recognizable groupings or in high incidence. Thus, CTV was likely introduced in low incidence, either by infected planting material or aphid transmission, and then spread within the plots, probably by multiple events over time. Therefore, we assume that the spatial relationships of infected trees to one another over time were indicative of the most likely distances over which transmission of the virus was most prevalent. From our findings, we could reject the null hypothesis that CTV spatial arrangement is random, at least for the spatial scales studied. Spread does not often appear to occur to immediately adjacent trees within or across rows more than would be expected from a random spatial process. However, CTV does appear to spread within a local area of influence defined by a radius equal to four to eight tree spaces.

The spatial processes discussed above are quite different from those reported previously for CTV epidemics in which A. gossypii was the predominant vector (21). Because A. gossypii is a migrator species and not generally a colonizer of citrus, it is only an infrequent visitor to citrus groves. Therefore, populations of $A$. gossypii tend to move through the orchard canopy in temporal waves from surrounding crop species (i.e., melon, cotton, and others) that are primary hosts for the aphid, with relatively few colonies being established in citrus (T. R. Gottwald, unpublished data). The migratory habit of $A$. gossypii in citrus was thought to account for a portion, if not all, of the apparently random spatial spread of CTV observed in the plots studied in Spain, much as it had been shown to do in California $(14,15,46)$ and is assumed to do in other areas where it and citrus coexist $(2,3,12,13,16,21,23,34)$. In these cases, the possibility of a nonrandom spatial structure of CTV incidence was not completely rejected, but rather hypothesized to exist, but at a larger, perhaps regional, scale beyond the dimensions of the plots studied. In Gibson's (19) recent reexamination of the spatio-temporal patterns of Spanish CTV data sets, results of stochastic model fitting pointed to the probability that the spatial processes leading to the CTV patterns in the field were not a purely random process, but more likely a combination of shortrange local transmissions and background infections from outside the plots.

Conversely, T. citricida is a colonizer species of citrus and can build up large populations in that host. When it was the predominant vector, CTV transmission was nonrandom within areas of local influence, as described above. One hypothesis to account for this nonrandom spatial pattern would be that at least some portion of the population of viruliferous $T$. citricida moved and transmitted CTV over short distances to nearby trees. Long-distance transmission of CTV by $T$. citricida (i.e., over distances greater than eight tree spaces) was not rejected, but if it occurred, it was beyond the dimensions of the plots studied or the abilities of the analyses employed to detect. The combination of large population buildups of T. citricida in citrus, CTV transmission efficiency several times 
that of other aphid vector species, and rapid short-range local dissemination of CTV appears to account for the rapid epidemic evolution seen once CTV is introduced into a citrus-growing area in the presence of $T$. citricida. Knowledge of pathosystem characteristics is important for making decisions concerning suppression and eradication efforts for CTV and to predict virus increase and spread when introduced into new areas.

\section{ACKNOWLEDGMENTS}

We thank the management and technical staff at Guanaranja, S. A., Santa Cecelia, Guanacaste, Costa Rica, Consorcio Citricola del Este, C \& A., Hato Mayor, Republica Dominicana, Consorcio Citricos Dominicana, Villa Altagracia, Republica Dominicana, and Oscar de la Renta Citrus Plantations, Bayaguana, Republica Dominicana, for cooperation in this project and help collecting samples. We also thank T. D. Riley, C. H. Henderson, and C. Halliday of the USDA-ARS, Orlando, FL, for technical assistance in processing samples, performing serological assays, and data processing.

\section{LITERATURE CITED}

1. Ballester-Olmos, J. F., Piña, J. A., Carbonell, E. A., Moreno, P., Hermoso de Mendosa, A., Cambra, M., and Navarro, L. 1993. Biological diversity of citrus tristeza (CTV) isolates in Spain. Plant Pathol. 42:219-229.

2. Bar-Joseph, M., and Loebenstein, G. 1972. Effects of strain source plant, and temperature on transmissibility of citrus tristeza virus by the melon aphid. Phytopathology 63:716-720.

3. Bar-Joseph, M., Roccah, B., and Loebenstein, G. 1977. Evaluation of the main variables that affect citrus tristeza virus transmission by aphids. Proc. Int. Soc. Citriculture 3:958-961.

4. Berger, R. D. 1981. Comparison of the Gompertz and logistic equations to describe plant disease progress. Phytopathology 71:716-719.

5. Cambra, M., Camarasa, E., Gorris, M. T., Garnsey, S. M., and Carbonell, E. 1991. Comparison of different immunosorbent assays for citrus tristeza virus (CTV) using CTV-specific monoclonal and polyclonal antibodies. Pages 38-45 in: Proc. Conf. Int. Organ. Citrus Virol., 11th. R. H. Brlansky, R. F. Lee, and L. W. Timmer, eds. IOCV, Riverside, CA.

6. Cambra, M., Camarasa, E., Gorris, M. T., Garnsey, S. M., Gumpf, D. J., and Tsai, M. C. 1993. Epitope diversity of citrus tristeza virus isolates in Spain. Pages 33-38 in: Proc. Conf. Int. Organ. Citrus Virol., 12th. P. Moreno, J. V. De Graça, and L. W. Timmer, eds. IOCV, Riverside, CA.

7. Cambra, M., Garnsey, S. M., Permar, M. A., Henderson, C. T., Gumpf, D. J., and Vela, C. 1990. Detection of citrus tristeza virus (CTV) with a mixture of monoclonal antibodies. (Abstr.) Phytopathology 80:1034.

8. Cambra, M., Serra, J., Bonet, J. C., and Villalba, D. 1990. Situación de la tristeza de los cítricos en la Comunidad Valenciana. Serie Fullets Divulgació 30. Ed. Generalitat Valenciana. Conselleria d'Agricultura I Pesca, Valencia, Spain.

9. Cambra, M., Serra, J., Villalba, D., and Moreno, P. 1988. Present situation of the citrus tristeza virus in the Valencian Community. Pages 1-7 in: Proc. Conf. Int. Organ. Citrus Virol., 10th. L. W. Timmer, S. M. Garnsey, and L. Navarro, eds. IOCV, Riverside, CA.

10. Campbell, C. L., and Madden, L. V. 1990. Introduction to Plant Disease Epidemiology. John Wiley \& Sons, New York.

11. Campbell, C. L., and Noe, J. P. 1985. The spatial analysis of soilborne pathogens and root diseases. Annu. Rev. Phytopathol. 23:129-148.

12. Chellemi, D. O., Rohrbach, K. G., Yost, R. S., and Sonoda, R. M. 1988. Analysis of the spatial pattern of plant pathogens and diseased plants using geostatistics. Phytopathology 78:221-226.

13. Chellemi, D. O., Sonoda, R. M., Pelosi, R. R., and Cohen, M. 1991. Temporal and spatial comparisons between epidemics of citrus blight and citrus tristeza virus. Pages 289-296 in: Proc. Conf. Int. Organ. Citrus Virol., 11th. R. H. Brlansky, R. F. Lee, and L. W. Timmer, eds. IOCV, Riverside, CA.

14. Dickson, R. C., Flock, R. A., and Johnson, M. McD. 1951. Insect transmission of citrus quick decline virus. J. Econ. Entomol. 44: 172-176.

15. Dickson, R. C., Johnson, M. McD., Flock, R. A., and Laird, E. F., Jr. 1956. Flying aphid populations in southern California citrus groves and their relation to the transmission of the tristeza virus. Phytopathology 46: 204-210.

16. Fishman, S., Marcus, R., Talpaz, H., Bar-Joseph, M., Oren, Y.,
Salomon, R., and Zohar, M. 1983. Epidemiological and economic models for spread and control of citrus tristeza virus disease. Phytoparasitica 11:39-49.

17. Garnsey, S. M., and Cambra, M. 1991. Enzyme-linked immunosorbent assay (ELISA) for citrus pathogens. Pages 193-216 in: Graft Transmissible Diseases of Citrus. C. N. Roistacher, ed. United Nations, Food Agric. Organ., Rome.

18. Garnsey, S. M., Gottwald, T. R., and Borbon, J. C. 1997. Rapid dissemination of mild isolates of citrus tristeza virus following introduction of Toxoptera citricida in the Dominican Republic. Pages 92-102 in: Proc. Conf. Int. Organ. Citrus Virol., 13th. P. Moreno, J. V. De Graça, and R. K. Yokomi, eds. IOCV, Riverside, CA.

19. Gibson, G. J. 1996. Investigating mechanisms of spatiotemporal epidemic spread using stochastic models. Phytopathology 87:139-146.

20. Gottwald, T. R., Cambra, M., and Moreno, P. 1993. The use of serological assays to monitor spatial and temporal spread of citrus tristeza virus in symptomless trees in eastern Spain. Pages 51-61 in: Proc. Conf. Int. Organ. Citrus Virol., 12th. P. Moreno, J. V. De Graça, and L. W. Timmer, eds. IOCV, Riverside, CA

21. Gottwald, T. R., Cambra, M., Moreno, P., Camarasa, E., and Piquer, J. 1996. Spatial and temporal analysis of citrus tristeza virus in eastern Spain. Phytopathology 86:45-55

22. Gottwald, T. R., Garnsey, S. M., Cambra, M., Moreno, P., Irey, M., and Borbón, J. C. 1997. Differential effects of Toxoptera citricida vs. Aphis gossypii on temporal and spatial patterns of spread of citrus tristeza. Pages 120-129 in: Proc. Conf. Int. Organ. Citrus Virol., 13th. P. Moreno, J. V. De Graça, and R. K. Yokomi, eds. IOCV, Riverside, CA.

23. Gottwald, T. R., Garnsey, S. M., Sediles-Jean, A., and Rojas-Solis, A. 1997. Co-diffusion of serologically distinct isolates of citrus tristeza virus vectored by Toxoptera citricida in northern Costa Rica. Pages 112119 in: Proc. Conf. Int. Organ. Citrus Virol., 13th. P. Moreno, J. V. De Graça, and R. K. Yokomi, eds. IOCV, Riverside, CA.

24. Gottwald, T. R., Richie, S. M., and Campbell, C. L. 1992. LCOR2-spatial correlation analysis software for the personal computer. Plant Dis. 76:213-215.

25. Hermoso de Mendoza, A., Ballester-Olmos, J. F., and Piña Lorca, J. A. 1984. Transmission of citrus tristeza virus by aphids (Homoptera: Aphididae) in Spain. Pages 23-27 in: Proc. Conf. Int. Organ. Citrus Virol., 9th. S. M. Garnsey, L. W. Timmer, and J. A. Dodds, eds. IOCV, Riverside, CA.

26. Hermoso de Mendoza, A., Ballester-Olmos, J. F., Piña, J. A., Serra, J., and Fuertes, C. 1988. Differences in transmission and efficiency of citrus tristeza virus by Aphis gossypii using sweet orange, mandarin or lemon trees as donor or receptor host plants. Pages 63-64 in: Proc. Conf. Int. Organ. Citrus Virol., 10th. L. W. Timmer, S. M. Garnsey, and L. Navarro eds. IOCV, Riverside, CA.

27. Hughes, G., and Madden, L. V. 1993. Using the beta-binomial distribution to describe aggregated patterns of disease incidence. Phytopathology 83:759-763.

28. Hughes, G., McRoberts, N., Madden, L. V., and Gottwald, T. R. 1997. Relationships between disease incidence at two levels in a spatial hierarchy. Phytopathology 87:542-550.

29. Hughes, G., McRoberts, N., Madden, L. V., and Nelson, S. C. 1997. Validating mathematical models of plant-disease progress in space and time. IMA J. Math. Appl. Med. Biol. 14:85-112.

30. Madden, L. V. 1986. Statistical analysis and comparison of disease progress curves. Pages 55-84 in: Plant Disease Epidemiology: Population Dynamics and Management. K. Leonard and W. E. Fry, eds. Macmillan, New York

31. Madden, L. V., and Hughes, G. 1994. BBD-Computer software for fitting the beta-binomial distribution to disease incidence data. Plant Dis. 78:536-540.

32. Madden, L. V., and Hughes, G. 1995. Plant disease incidence: Distributions, heterogeneity, and temporal analysis. Annu. Rev. Phytopathol. 33: 529-564.

33. Madden, L. V., Louie, R., Abt, J. J., and Knoke, J. K. 1982. Evaluation of tests for randomness of infected plants. Phytopathology 72:195-198

34. Marcus, R., Fishman, S., Talpaz, H., Salomon, R., and Bar-Joseph, M. 1984. On the spatial distribution of citrus tristeza virus disease. Phytoparasitica 12:45-52.

35. Modjeska, J. S., and Rawlings, J. O. 1983. Spatial correlation analysis of uniformity data. Biometrics 39:373-384.

36. Moreno, P., Piquer, J., Piña, J. A., Juarez, J., and Cambra, M. 1988. Spread of citrus tristeza virus in a heavily infested citrus area in Spain. Pages 71-76 in: Proc. Conf. Int. Organ. Citrus Virol., 10th. L. W. Timmer, S. M. Garnsey, and L. Navarro, eds. IOCV, Riverside, CA.

37. Noe, J. P., and Campbell, C. L. 1985. Spatial pattern analysis of plant 
parasitic nematodes. J. Nematol. 17:86-93.

38. Permar, T. A., Garnsey, S. M., Gumpf, D. J., and Lee, R. F. 1990. A monoclonal antibody that discriminates strains of citrus tristeza virus. Phytopathology 80:224-228.

39. Rocha-Peña, M. A., Lee, R. F., Lastra, R., Nibblet, C. L., Ochoa-Corona, F. M., Garnsey, S. M., and Yokomi, R. K. 1995. Citrus tristeza virus and its aphid vector Toxoptera citricida. Plant Dis. 79:437-445.

40. Schwarz, R. E. 1965. Aphid-borne virus diseases of citrus and their vectors in South Africa. B. Flight activity of citrus aphids. S. Afr. J. Agric. Sci. 8:931-940.

41. Upton, G., and Fingleton, B. 1984. Spatial data analysis by example. John Wiley \& Sons, Chichester, England.

42. Vela, C., Cambra, M., Cortés, E., Moreno, P., Miguet, J. G., Pérez de San Román, C., and Sanz, A. 1986. Production and characterization of monoclonal antibodies specific for citrus tristeza virus and their use for diagnosis. J. Gen. Virol. 67:91-96.
43. Vela, C., Cambra, M., Sanz, A., and Moreno, P. 1986. Use of specific monoclonal antibodies for diagnosis of citrus tristeza virus. Pages 55-61 in: Proc. Conf. Int. Organ. Citrus Virol., 10th. L. W. Timmer, S. M. Garnsey, and L. Navarro, eds. IOCV, Riverside, CA.

44. Yokomi, R. K., Garnsey, S. M., Civerolo, E. L., and Gumpf, D. J. 1989. Transmission of exotic citrus tristeza isolates by a Florida colony of Aphis gossypii. Plant Dis. 73:552-556.

45. Yokomi, R. K., Lastra, R., Stoetzel, M. B., Damsteegt, V. D., Lee, R. F., Garnsey, S. M., Gottwald, T. R., Rocha-Peña, M. A., and Nibblet, C. L. 1994. Establishment of the brown citrus aphid (Homoptera: Aphididae) in Central America and the Caribbean Basin. J. Econ. Entomol. 88:1078-1085.

46. Yokomi, R. K., and Oldfield, G. N. 1991. Seasonal fluctuations of alate aphid activity in California citrus groves. Pages 71-76 in: Proc. Conf. Int. Organ. Citrus Virol., 11th. R. H. Brlansky, R. F. Lee, and L. W. Timmer, eds. IOCV, Riverside, CA. 